\title{
TREND ONTOLOGIS DAN EPISTEMOLOGIS KAJIAN HUKUM ISLAM
}

\author{
Mohammad Hefni \\ (Pascasarjana STAIN Pamekasan, jln. Pahlawan KM. 4 Pamekasan, email: \\ Hefni_mohd@yahoo.com, HP. 0818582 317)
}

\begin{abstract}
Abstrak
Sebagai bagian dari studi Islam, studi hukum Islam pada awalnya bersifat normatif. Dalam perkembangannya, beberapa ahli hukum Islam memperluas pola-pola kajian pada hukum Islam nondoktrinal yang lebih bersifat sosiologis. Belakangan muncul kecenderungan baru kajian hukum Islam yang mencoba mensintesiskan kajian hukum Islam doktriner dan nondoktriner. Di sisi lain, secara ontologis, kajian hukum Islam mengenal kajian pembidangan, seperti kajian figh ahwâl al-syakhshiyyah, figh ibâdah, fiqh $m u$ 'âmalah, dan kajian geografis, seperti kajian hukum Islam global, kawasan, dan lokal. Secara epistemologis dan ontologis, model-model kajian hukum Islam di atas telah dilakukan oleh mahasiswa Prodi Ahwâl al-Syakhshiyyah STAIN Pamekasan. Ini dibuktikan oleh 33 kajian skripsi mahasiswa yang merambah pada model-model kajian tersebut. Lebih dari itu, secara sosiologis, penelitian ini disebut sebagai penelitian lokalitas, yakni penelitian yang mengambil lokus Madura.
\end{abstract}

\begin{abstract}
As a part of Islamic study, Islamic law study, at first, was normative. In its development, some experts of it broaden the styles of studies on non doctrinal Islamic law which has more sociology. Then, it appears the new tendency of the Islamic law study trying to synthesize it of doctrinaire and nondoctrinaire. On the other hand, it discusses classification of the study based on ontology, such as figh ahwâl alsyakhshiyyah, figh ibâdah, figh mu'âmalah, and geography study, like global and local Islamic law study. The models of Islamic law studies above have been conducted by students of STAIN Pamekasan, based on epistemology and ontology. It is evidenced that 33 students' researches are discussions about those models. Moreover, sociologically, this study is referred
\end{abstract}


to as the study of locality, namely research that took locus in Madura.

\author{
Kata-kata Kunci \\ Epistemologis, ontologis, hukum Islam, doktrinal, sosiologis, \\ bayâni, burhâni.
}

\title{
Pendahuluan
}

Studi hukum Islam merupakan sebagian dari studi Islam pada umumnya. Studi keislaman yang mulanya bercorak teologis kini mulai merambah pada kajian-kajian sosiologis, eksakta dan humaniora. Beberapa cendekiawan Muslim mulai menawarkan kajian keislaman yang berdimensi normatif dan sosiologis dengan beragam istilah. Fazlur Rahman, misalnya, memberikan istilah normative Islam dan historical Islam, ${ }^{1}$ Amin Abdullah memberikan istilah sebagai kajian keislaman normativitas dan historisitas, ${ }^{2}$ dan Akh. Minhaji mengistilahkan terhadap keduanya sebagai normative Islam dan empirical Islam. ${ }^{3}$ Studi hukum Islam pun mengalami nasib serupa.

Awalnya, studi atas hukum Islam bersifat normatif. Sejarah epistemologis studi hukum Islam secara normatif sesungguhnya dimulai sejak zaman yang amat dini dalam Islam, yaitu sejak alSyâfi'în ${ }^{4}$ menggarap metodologi studi hukum Islam dalam karyanya alRisâlah. Dalam karyanya ini, metode yang ditawarkan oleh al-Syâfi'î lebih bercorak teologis-deduktif dengan paradigma literalistik. Dalam

1 Fazlur Rahman. "Islamic Modernism: Its Scope, Method and Alternative." International Journal of Middle East 1 (1970), hlm. 317-32.

2 Amin Abdullah, "Paradigma Alternatif Pengembangan Usul Fiqh", dalam Mazhab Jogja: Menggagas Paradigma Ushul Figh Kontemporer (Yogyakarta: AR-RUZZ Press, 2002)

${ }^{3}$ Akh. Minhaji, "Pendekatan Sejarah dalam Kajian Hukum Islam," Mukaddimah No. 8 Th V/1999, 63-88. Lihat juga Idem, "A Problem of Methodological Approach to Islamic Law Studies", al-Jami'ah Journal of Islamic Studies, No. 63/VI (1999)

4 Nama lengkapnya adalah Abû Abdillâh Muhammad bin Idrîs bin al-Abbâs bin Utsmân bin Syâfi'î bin al-Saib bin ‘Ubayd bin Abdi Yâzid bin Hasyim bin Abdi Manaf dari suku Quraysy. Ia dilahirkan di kota Gazzah Palestina pada tahun 150 H., tahun bertepatan dengan tahun wafatnya Abû Hanîfah. Secara nasab, beliau bertemu dengan Nabî saw di Abdi Manaf. Jadi beliau masih termasuk dalam kategori kerabat Nabî dan satu suku dan marga. Sedangkan dari pihak ibu, riwayat yang masyhur mengatakan bahwa ibunya berasal dari suku $\mathrm{Azd}$. Beliau populer dengan sebutan alSyâfi ii, sebagai nisbah kepada kakek ke-4 beliau. Baca Sulaymân al-Asyqar, al-Imâm alSyâfi'î (Kairo: Dâr al-Salam, tt.). 
paradigma literalistik kajian terhadap teks bahasa Arab lebih dominan, baik dari segi grammar (tata bahasa) maupun sintaksisnya dan mengabaikan kajian terhadap maksud dasar wahyu yang ada di balik teks literal. ${ }^{5}$

Kondisi semacam ini dapat dipahami karena ushîl al-figh sendiri, yang nota bene merupakan induk dasar metode penemuan Islam itu sendiri, selalu didefinisikan sebagai "seperangkat kaidah untuk istinbâth hukum syar'î amalî dari dalil-dalilnya yang tafshîlî". ${ }^{6}$ Istilah yang tidak pernah lepas tertinggal dari semua definisi ushûl alfigh tersebut adalah kalimat "dari dalil-dalilnya yang tafshîlı". Ini memberi kesan sekaligus membuktikan bahwa kajian metode hukum Islam memang terfokus dan tidak lebih dari pada analisis teks. Lebih dari itu, definisi di atas juga memberi petunjuk bahwa hukum dalam Islam hanya dapat dicari dan diderivasi dari teks-teks wahyu saja (law in book). Bahkan secara tegas, Hasyim Kamali menyebut bahwa ushîl al-figh merupakan ilmu yang menjelaskan sumber-sumber hukum dan sekaligus metode deduksi hukum dari sumber-sumber tersebut.7

Dalam perkembangannya, beberapa ahli hukum Islam memperluas pola-pola kajian, tidak terbatas pada kajian hukum Islam doktrinal yang bersifat normatif, tetapi juga kajian hukum Islam non doktrinal yang lebih bersifat sosiologis. Usaha ini telah dilakukan oleh para pemikir hukum Islam klasik seperti al-Ghazâlî dengan metode induksi dan tujuan hukumnya maupun al-Syâthibî dengan induksi tematisnya. ${ }^{8}$ Di sini, al-Syâthibî mengembangkan konstruksi metodologi figh berbasis kepedulian sosial. Tentu saja, "cetak tebal" tidak hanya terletak pada kemapanan metodologi figh-nya, tetapi juga

\footnotetext{
${ }^{5}$ Dengan meminjam kerangka analisis al-Jabiri, model berpikir yang memusatkan pada kajian teks dan bahasa pada umumnya dikategorikan sebagai corak berpikir yang menggunakan epistimologi bayâni, yang berbeda secara tegas dengan model berpikir yang menggunakan epistemologi burhâni, dan lebih-lebih irfani. Lihat Amin Abdullah, "Paradigma Alternatif Pengembangan Usul Fiqh", dalam Mazhab Yogya, hlm. 118

${ }^{6}$ Abd al-Wahhab Khallâf, 'Ilm Ushûl al-Figh, (Kuwait: Dâr al-Qalam, tt.), hlm. 12.

7 M. Hasyim Kamali, Principles of Islamic Jurisprudence (Cambridge: The Islamic Texts Society, 1991), hlm. 1

8Syamsul Anwar, "Teori Hukum Hukum Islam al-Ghazali dan Pengembangan Metode Penemuan Hukum Islam", dalam M. Amin Abdullah et al., Tafsir Baru Studi Islam dalam Era Multi Kultural (Yogyakarta: Kurnia Kalam Semesta, 2002), hlm. 198.
} 
keberaniannya menerobos status quo para fuqahấ menghadapi problem-problem baru dan mendobrak sikap simplistis.

Munculnya kesenjangan antara figh dan perubahan sosial, menurut al-Syâthibî, merupakan akibat dari fuqahấ yang sudah merasa puas dengan menghimpun dan membukukan hukum-hukum, permasalahan-permasalahan, dan hasil-hasil ijtihâd masa lalu. Selanjutnya, mereka dijadikan teks dan terakhir dikeluarkan kembali guna menjawab sejumlah persoalan yang muncul belakangan. Hukum-hukum yang dikeluarkan sejumlah ulama' terdahulu diupayakan menjadi pengganti paling berharga dari kekeringan pemikiran dan kebekuan ilmiyah mereka. ${ }^{9}$ Gugatan al-Syâthibî ini mengandung nilai universal, bahka jika hendak menyikapi persoalan kontemporer secara kreatif, maka pemikiran atas pemikiran para ulama' terdahulu seharusnya bukan dalam bentuk pelestarian hukum itu apa adanya, dan dengan cara mendialogkan secara kreatif-dinamis dengan kondisi mutakhir.

Gagasan-gagasan ahli ushîl klasik-utulitarisnis, terutama alSyâthibî, kemudian menjadi paradigma mapan dalam kesadaran metodologis Muhammad 'Abduh dan Muhammad Rasyîd Ridlâ. Indikasi yang menunjukkan hal ini adalah kesepakatan Abduh dan Ridlâ dengan postulat teoritis Syâthibî ala Muktazilî yang menyatakan bahwa "hukum Tuhan ditetapkan untuk kemaslahatan manusia".10 Namun, 'Abduh dan Ridlâ tidak menawarkan gagasan baru, melainkan hanya sekedar mencoba mengartikulasikan konsep maqâshid al-syarî'ah yang ditelorkan oleh ahli ushûl sebelumnya.

Selain 'Abduh dan Ridlâ, Hallaq juga mengkategorikan 'Allal al-Fasi sebagai penganut utilitarianisme.11 Al-Fasi dengan kecenderungan rasionalnya berambisi mengimplementasikan ide-ide maqâshid al-Syâthibî dalam ranah isu-isu kontemporer.12 Fasi yakin

\footnotetext{
9 Mun'im A. Sirry, "Memperkenalkan Fiqh Abu Ishaq al-Syathibi”, Jurnal Ulumul Qur'an, Vol. V No. 1 (1999), hlm. 88.

${ }^{10}$ Hammadi al-'Ubaydi, al-Syâthibî wa Maqâshid al-Syarî'ah (Tripoli: Lajnah al-Huffâdz 'alâ al-Turâts al-Islâmî, 1992), hlm. 101.

11 Wael B. Hallaq, Sejarah Teori Hukum Islâm: Pengantar Ushul Figh Madzhab Sunni, terj. E. Kusnadiningrat dan Abdul Haris bin Wahid (Jakarta: PT Raja Grafindo Persada, 2000), hlm. 318

12 Nûr al-Dîn Butsurî, Maqâshid al-Syarî'ah: al-Tasyrî' al-Islâmî al-Mu'âshir bayn Tsumuh al-Mujtahid wa Qushûr al-Ijtihâd, (Bairut: Dâr al-Thali'ah, 2000), hlm. 92.
} 
bahwa dialektika antara teori maqâshid dengan isu-isu kontemporer akan menciptakan keharmonisan yang sinergi antara maqâshid dengan realitas sosial yang belakangan senjang. Untuk mewujudkan impian adiluhung itu, Fasi harus rela menceburkan dirinya dalam persoalanpersoalan kompleks seperti keadilan sosial, egalitarianisme (musâwah), poligami, freedom (huriyyah), hak asasi manusia, sistem demokrasi, dan sebagainya. ${ }^{13}$

Dalam kaitan ini, salah seorang pakar hukum Islam, Muhammad Atho' Mudzhar ${ }^{14}$ menawarkan studi hukum Islam secara sosiologis. Ia membagi pola studi hukum Islam dalam tiga kategori. Pertama, studi hukum Islam sebagai doktrin azas. Sasaran utamanya adalah dasar konseptual hukum Islam, seperti Filsafat hukum Islam, sumber hukum Islam, konsep dasar (maqâshid syarî'ah, qawâ'id alfiqhiyyah, manhaj al-ijtihâd dan lain-lain). Kedua, studi hukum Islam normatif. Dalam pola ini, sasaran utama studinya adalah hukum Islam sebagai aturan/norma baik yang berupa nash (ayat-ayat ahkâm dan hadits-hadits ahkâm) maupun produk ijtihâd (kitab fiqh, keputusan pengadilan, undang-undang, fatwa ulama, kompilasi hukum Islam, dan sebagainya). Ketiga, studi hukum Islam sebagai gejala sosial (social fenomena). Sasaran utamanya adalah perilaku hukum masyarakat Muslim dan interaksi antara Muslim dengan Muslim atau Muslim dengan non Muslim di seputar hukum Islam. Pola studi hukum Islam yang disebut pertama dan kedua disebut sebagai kajian hukum Islam doktriner, sedangkan pola ketiga disebut sebagai studi hukum Islam non doktriner.

Akhir-akhir ini muncul kecenderungan baru kajian hukum Islam yang mencoba mensintesiskan kajian hukum Islam doktriner dan non doktriner. Pendekatan baru ini, misalnya, diperkenalkan oleh Louay Safi. Dalam usulannya, Safi terlebih dahulu menjelaskan bagaimana setiap pengetahuan tidak bisa lepas dari pra-anggapan tertentu atau tidak bebas nilai (value free); bagaimana wahyu juga mengandung suatu rasionalitas tertentu dan bagaimana realitas

\footnotetext{
13 Ibid., hlm. 66-86.

${ }^{14}$ M. Atho' Mudzhar, "Pendekatan Sosiologi dalam Studi Hukum Islam", dalam M. Amin Abdullah, et al., Mencari Islam: Studi Islam dengan Berbagai Pendekatan. (Yogyakarta: Tiara Wacana, 2000), hlm. 34-35.
} 
wahyu dan realitas empiris sama-sama bisa menjadi sumber pengetahuan.

Di sisi lain, secara ontologis, kajian hukum Islam mengenal kajian pembidangan dan kajian geografis. Secara pembidangan, kajian hukum Islam dibagi ke dalam lingkup figh ahwâl al-syakhshiyyah (hukum keluarga/perdata Islam), figh ibâdah, figh mu'âmalah, fiqh llmiyah, figh siyâsah (politik), figh jinâyah (pidana), figh qadha' (peradilan), figh jender, figh al-thib (kesehatan), figh al-faniyah (kesenian), figh ekologi (lingkungan), dan figh al-ijtimâ'iyah (sosial). ${ }^{15}$

Dalam kajian geografis, hukum Islam mengenai kajian global, kawasan, dan lokal. Dalam kajian global mengandaikan mahasiswa mengkaji hukum Islam di belahan dunia Islam dan kajian kawasan mengantarkan mahasiswa untuk mengkaji Islam di kawasan dunia Islam, seperti Asia Tenggara. Timur Tengah, dan sebagainya. Sedangkan dalam kajian lokal, mahasiswa mengkaji hukum Islam di komunitas, suku bangsa, atau dalam geografi adaptasi ekologi tertentu.

Secara epistemologis dan ontologis, model-model kajian hukum Islam di atas sangat mungkin telah dilakukan oleh mahasiswa Prodi AHS STAIN Pamekasan. Karenanya, tulisan ini difokuskan pada dua persoalan, yaitu: Pertama, bagaimana trend ontologis kajian hukum Islam di STAIN Pamekasan? Apakah ia berada dalam lingkup studi global, studi kawasan ataukah studi lokalitas? Kedua, bagaimana trend epistemologis kajian hukum Islam di STAIN Pamekasan? Apakah ia bersifat doktriner, empiris, ataukah doktriner-empiris?

Secara materi, penelitian ini dibatasi pada penelitian skripsi mahasiswa Program Studi Ahwal al-Syakhshiyyah (AHS) Jurusan Syari'ah STAIN Pamekasan tahun 2013 yang berjumlah 33 judul.

\section{Kajian Terdahulu}

Penelitian ini dilakukan karena hingga saat ini, penelitian yang secara serius mendalami tentang kajian hukum Islam di perguruan tinggi bisa dikatakan tidak banyak. Salah satunya adalah penelitian yang dilakukan oleh Akh. Minhaji dan Kamaruzzaman Bustamam-Ahmad. Dalam tulisannya berjudul "Arah Baru Studi

15 Cik Hasan Basri (ed.), Kompilasi Hukum Islam dan Peradilan Agama dalam Sistem Hukum Nasional (Jakarta: Logos, 1999). 
Hukum Islam di Indonesia", 16 mereka mengambil studi kasus di IAIN Sunan Kalijaga Yogyakarta dengan materi kajian kurikulum dan silabus Fakultas Syari'ah. Temuannya adalah bahwa studi hukum Islam di IAIN ini masih belum menampakkan perkembangan yang menggembirakan. Kajian hukum Islam hukum Islam di IAIN ini masih sangat klasik dan teologis-normatif-dekuktif.

Hasil kajian diperkuat oleh penelitian yang dilakukan oleh Syamsul Anwar. Menurutnya, kajian hukum Islam di IAIN tampak lebih banyak terfokus pada pendekatan atomistik dan tekstual.17 Temuan yang sama juga ditemukan dalam hasil penelitian yang dilakukan oleh oleh Musahadi HAM. ${ }^{18}$ Dalam kajiannya berjudul "Pemikiran Ulang Perguruan Tinggi Agama", ia menyimpulkan bahwa studi keislaman, termasuk hukum Islam, di Indonesia, termasuk di PTAI pada umumnya mengidap problem epistemologis yang serius, yakni studi keislaman lebih kental dengan pendekatan rasionalisme spekulatif yang berwatak deduktif. Sementara pendekatan empirisme praktis yang berwatak induktif kurang mendapat tempat yang layak. Selama ini pengembangan keilmuan keislaman di PTAI relatif stagnan karena kuatnya pendekatan normative-teologis, sehingga yang terjadi adalah justifikasi terhadap kebenaran ajaran, doktrin, dan teori-teori normatif agama.

Kajian atas hukum Islam lainnya, terutama terhadap kurikulum, dilakukan oleh Nur A. Fadhil Lubis. ${ }^{19}$ Dalam kajiannya berjudul "Pengembangan Studi Hukum Islam di IAIN" ia menemukan adanya sinkronisasi antara nama dengan entitas yang diberi nama. Artinya, hasil pelurusan terhadap kurikulum Fakultas Syari'ah selama ini dapat disimpulkan bahwa yang dipelajari memang syari'ah yang bukan hanya terfokus pada fikih, apalagi

${ }^{16}$ Akh. Minhaji dan Kamaruzzaman Bustamam-Ahmad, "Arah Baru Studi Hukum Islam di Indonesia", Jurnal Perta, Vol. VI/03 (2005)

17 Syamsul Anwar," Pengembangan Metode Penelitian Hukum Islam " dalam Mazhab Jogja: Menggagas Paradigma Ushul Figh Kontemporer, (Yogyakarta: AR-RUZZ Press, 2002), hlm.147-148.

18 Musahadi HAM, "Pemikiran Ulang Perguruan Tinggi Agama", Suara Merdeka, tanggal 11 Juli 2009.

${ }^{19}$ Nur A. Fadhil Lubis, "Pengembangan Studi Hukum Islam di IAIN", Jurnal Perta, Vol. VII/2 (2010) 
terbatas pada hukum semata. Dengan kata lain, kajian hukum Islam di Indonesia masih bersifat doktriner.

Dengan mengkaji kurikulum, semua penelitian di atas menyimpulkan bahwa kajian hukum Islam di IAIN dan PTAI secara umum secara epistemologis masih bersifat deduktif-normatif dan kurang memberikan tempat yang layak bagi kajian hukum Islam yang bersifat induktif-empiris. Penelitian ini berbeda dengan penelitian di atas, karena dengan mengambil obyek kajian atas penelitian dosen dan penelitian skripsi mahasiswa, secara epistemologis membuka ruang bagi kajian hukum Islam, baik yang bersifat deduktif-normatif, induktif-empiris, bahkan yang bersifat integralistik. Secara ontologis, penelitian ini juga akan membuka peluang bagi studi lokalitas (kemaduraan) sehingga menjadi ciri khas penelitian di STAIN Pamekasan.

\section{Hermeneutika Schleiermacher sebagai Perspektif Teoritik}

Perspektif teoritik yang digunakan dalam penelitian ini adalah hermeneutika Friedrich Schleiermacher (1768-1834). Kata "hermeneutik" berasal dari bahasa Yunani hermeneuein yang berarti "menafsirkan", dan kata bendanya hermeneia yang berarti "penafsiran" atau "interpretasi", dan kata hermeneutes yang berarti interpreter (penafsir). Istilah Yunani berkenaan dengan kata "hermenuetik" ini dihubungkan dengan nama dewa Hermes dalam epik karya Homerus dalam Eliliad dan Oddyssey. Dikisahkan bahwa Hermes adalah seorang utusan yang bertugas menyampaikan pesan-pesan Jupiter kepada umat manusia. Tugas Hermes menerjemahkan pesan-pesan dari dewa di Gunung Olympus itu ke dalam bahasa yang dapat dimengerti oleh manusia. Fungsi dari Hermes adalah sangat penting sebab jika terjadi kesalahpahaman dalam menginterpretasikan pesan dewa akibatnya akan fatal bagi umat manusia. Sejak itu Hermes menjadi simbol seorang duta yang ditugasi menginterpretasikan pesan, dan berhasil tidaknya tugas itu sepenuhnya tergantung bagaimana pesan tersebut disampaikan. ${ }^{20}$

Berangkat dari mitos Yunani itu, kata "hermeneutik" diartikan sebagai "proses mengubah sesuatu atau situasi ketidaktahuan

20 E. Sumaryono, Hermeneutik: Sebuah Metode Filsafat (Yogyakarta: Kanisius,1999), hlm. 23-24. 
menjadi mengerti", terutama proses ini melibatkan bahasa sebab bahasa merupakan mediasi paling sempuma dalam proses..$^{21}$ Senada ini Palmer, Zygmunt Bauman mengartikan hermeneutika sebagai upaya menjelaskan dan menelusuri pesan dan pengertian dasar dari sebuah ucapan atau tulisan yang tidak jelas, kabur, remang-remang, dan kontradiktif, yang menimbulkan kebingungan bagi pendengar atau pembaca. ${ }^{22}$

Hermeneutika schleiermarher berpijak pada prinsip dasar bahwa teks merupakan ekspresi perangkat linguistik yang mentransformasikan ide pengarang kepada pembaca. ${ }^{23}$ Poin penting lain dalam pemikiran universal hermeneutika Schleiermacher adalah persamaan sikap atau perlakuan antara Bibel dengan teks karya manusia. Karena permasalahan tidak terletak pada materi akan tetapi cara memahaminya. Sebagai konsekuensinya, kajian filologi teks dan teologi dalam Bibel disubordinasikan kepada problem penafsiran yang umum. Schleiermacher juga berpendapat bahwa kesalahpahaman dalam interpretasi berakar pada perbedaan pandangan hidup dan sebagainya yang disebabkan oleh perbedaan zaman dan rentang waktu antara pengarang dan penafsir. Makna sebenarnya sebuah teks didapatkan dengan rekonstruksi historis saat teks tersebut ditulis. Jadi apa yang dimaksud oleh sebuah teks bukanlah apa yang kelihatannya dikatakan kepada sang pembaca.

Dalam hubungan ini, Friedrich Schleiermacher (1768-1834), menyatakan bahwa ketika teks dilempar ke ruang publik, ia tidak bisa hidup dengan nafasnya sendiri. Dengan kata lain, makna teks adalah makna yang dikehendaki oleh pengarangnya. Karenanya, penafsiran merupakan sebuah kegiatan reproduktif, yakni memberikan makna dengan tidak terlepas dari pengarangnya..24 Bahkan menurutnya, seorang penafsir harus masuk ke dalam waktu dan alam pikiran pengarangnya. Seorang penafsir mesti membayangkan dan mengkonfirmasi bagaimana pemikiran dan maksud pengarang.

${ }^{21}$ Richard E. Palmer, Hermeneutika: Teori Baru Mengenai Interpretasi, terj. Musnur Hery (Yogyakarta: Pustaka Pelajar, 2003), hlm. 15.

22Fakhruddin Faiz, Hermeneutika al-Qur'an (Yogyakarta: Qolam, 2002), hlm. 22.

23 Nashr Hamid Abu Zaid, Hermeneutika Inklusif (Yogyakarta: PT LKIS Pelangi Aksara, 2004), hlm. 15.

24 Kees Bertens, Filsafat Barat dalam Abad XX (Jakarta: Gramedia, 1981), hlm. 231. 
Kemudian, dalam tradisi yang sama, Wilhelm Dilthey (18331911) mengembangkan hermeneutika sebagai landasan bagi ilmu kemanusiaan (Geisteswissenschaften). Ia mengatakan bahwa meskipun orang tidak dapat mengalami secara langsung (erleben) peristiwaperistiwa di masa lampau, tetapi ia dapat membayangkan bagaimana orang-orang dulu mengalaminya (nacherleben). ${ }^{25} \mathrm{Di}$ sini Dilthey, sebagaimana Schleiermacher, sama-sama menekankan pada kemampuan seorang penafsir untuk keluar dari kungkungan sejarahnya sendiri dan masuk ke dalam dunia orang lain, dunia orang yang menyusun teks, sehingga bisa merasakan dan menghayati keadaannya.

Hermeneutika Schleiermacher menjadi pilihan perspektif teoritis untuk memahami teks-teks dalam penelitian skripsi mahasiswa Prodi AHS. Ini didasarkan atas pertimbangan bahwa dalam memaknai teks-teks tersebut, peneliti tidak bisa melepaskann diri dari perspektif penulis (mahasiswa). Di sini, peneliti tidak melakukan interpretasi bebas yang terlepas dari kehendak penulisnya.

\section{Metode Kajian}

Studi ini menggunakan pendekatan kualitatif dan memadukan antara jenis penelitian pustaka (library research) dan jenis penelitian lapangan (field research). Oleh karena itu, sumber data yang diperlukan berasal dari bahan-bahan tertulis dan bahan-bahan yang diperoleh lapangan.

Sumber data primer untuk bahan-bahan tertulis diperoleh dari studi dokumentasi atas hasil penelitian skripsi mahasiswa Program Studi Ahwal al-Syakhshiyyah (AHS) tahun 2013 yang keseluruhannya berjumlah 33 karya. Sedangkan sumber sekunder adalah tulisantulisan yang memiliki relevansi dengan penelitian ini, seperti bukubuku penelitian dan buku-buku atau tulisan-tulisan yang mengurai konsep ontologis dan empistemologis kajian hukum Islam. Data yang diperoleh dari bahan-bahan tertulis kemudian dianalisis dengan menggunakan teknik content analysis (analisis isi), ${ }^{26}$ suatu teknis

${ }^{25}$ Ibid., hlm. 228.

${ }^{26}$ Noeng Muhajir, Metode Penelitian Kualitatif (Yogyakarta: Rake Sarasin, 1996), hlm. 49 Lihat juga Bungin Burhan, Analisis Data Penelitian Kualitatif: Pemahaman Filosofis dan 
analisis data tentang pesan atau isi suatu komunikasi. Dengan teknik ini, peneliti akan melakukan analisis kritis atas hasil-hasil penelitian mahasiswa Prodi AHS tahun 2013 baik dari sisi ontologis maupun epistemologis.

Data dari bahan-bahan tertulis tersebut kemudian dipadukan dengan data yang diperoleh di lapangan melalui wawancara mendalam (indepth interview) dan Focused Group Discussion). Wawancara dan FGD ini dilakukan terhadap mahasiswa yang melakukan penelitian.

Di dalam wawancara dan FGD ini, peneliti lebih banyak bertindak sebagai pendengar di antara percakapan mereka. Di sini peneliti memperlakukan penulis karya tersebut sebagai orang yang ahli dalam pengalamannya sendiri. Di samping itu, dalam pelaksanaan wawancara ini lebih bersifat dialog daripada mengendalikan pembicaraan mereka. ${ }^{27}$

Sedangkan analisis data dalam studi lapangan ini menggunakan analisis model interaktif. ${ }^{28}$ Dengan mengikuti model ini, analisis data berlangsung secara simultan yang dilakukan bersamaan dengan proses pengumpulan data, dengan tahapan alur sebagai berikut: Pengumpulan data, display data, reduksi data, dan menarik kesimpulan atau verifikasi. ${ }^{29}$

Untuk menjaga keabsahan data, peneliti menggunakan cara yang disarankan oleh Noeng Muhajir, ${ }^{30}$ yaitu (1) menguji tercapainya temuan, (2) mengadakan pertemuan kelompok peneliti untuk menghindarkan bias dan ketidakjelasan, (3) menguji hasil temuan tentatif dan penafsiran rekaman, audio, foto dan semacamnya.

Metodologis ke Arah Penguasaan Model Aplikatif (Jakarta: Raja Grafindo Persada, 2008), hlm. 38 .

27Miron Orleans, The Qualitative Report, Volume 3, Number 2, July 1997. Http://www.nova.ede/sss/QR3 3-2/wrn.html

${ }_{28}$ Matthew B. Miles dan A. Michael Hubermas, An Expanded Source Book: Qualitative Data Analysis (London: Sage Publication, 1995), hlm. 10-14.

29 S. Nasution, Metode Penelitian Naturalistik-Kualitatif (Bandung: Tarsito, 1992), hlm. 128-130.

30 Muhajir, Metodologi Penelitian, hlm. 126. 


\section{Trend Ontologis Kajian Hukum Islam di STAIN Pamekasan}

Secara keseluruhan terdapat 33 judul skripsi mahasiswa yang lulus pada tahun 2013. Judul-judul tersebut adalah:

\begin{tabular}{|c|c|c|}
\hline NO & JUDUL & PENULIS \\
\hline 1 & $\begin{array}{l}\text { Kepercayaan Masyarakat terhadap } \\
\text { Primbon Pernikahan Perspektif Hukum } \\
\text { Islam di Desa Plakpak Kecamatan } \\
\text { Pegantenan Kabupaten Pamekasan }\end{array}$ & Ahmad Efendi \\
\hline 2 & $\begin{array}{l}\text { Pandangan Ibn Qoyyim al-Jauziyah } \\
\text { terhadap al-Hiyal al-Syar'iyah dalam } \\
\text { Praktik Hibah Waris }\end{array}$ & Mahbubi \\
\hline 3 & $\begin{array}{l}\text { Kesadaran Suami Istri dalam Memiliki } \\
\text { Akta Kelahiran bagi Anak yang } \\
\text { Dilahirkan pada Masyarakat Desa } \\
\text { Polagan Kecamatan Galis Kabupaten } \\
\text { Pamekasan }\end{array}$ & Sri Windartik \\
\hline 4 & $\begin{array}{l}\text { Saksi Palsu dalam Proses Perceraian di } \\
\text { Pengadilan Agama Pamekasan }\end{array}$ & Hairuddin \\
\hline 5 & $\begin{array}{l}\text { Etika Profesi Advokat dalam Perspektif } \\
\text { Hukum Islam dan Hukum Positif }\end{array}$ & Syaiful Ridho \\
\hline 6 & $\begin{array}{l}\text { Pandangan } \quad \text { Masyarakat tentang } \\
\text { Pelaksanaan Pencatatan Perkawinan di } \\
\text { Desa Waru Barat Kecamatan Waru } \\
\text { Kabupaten Pamekasan }\end{array}$ & Rismawati \\
\hline 7 & $\begin{array}{l}\text { Faktor Pendapatan Suami dan Istri dalam } \\
\text { Membangun Keharmonisan Rumah } \\
\text { Tangga di Kelurahan Parteker Kecamatan } \\
\text { Kota Kabupaten Pamekasan }\end{array}$ & Sulaihah \\
\hline 8 & $\begin{array}{l}\text { Penerapan Kebijakan Pengukuran Arah } \\
\text { Kiblat Kementerian Agama Kabupaten } \\
\text { Pamekasan }\end{array}$ & Hairul Umam \\
\hline 9 & $\begin{array}{l}\text { Implementasi Zakat Gaji di Kalangan } \\
\text { PNS Pada Kantor Kementerian Agama } \\
\text { Kabupaten Pamekasan }\end{array}$ & Akhmad Maimun \\
\hline
\end{tabular}




\begin{tabular}{|c|c|c|}
\hline 10 & $\begin{array}{l}\text { Analisis Hukum Islam atas Putusan } \\
\text { Mahkamah Konstitusi } \quad \text { No } 46 \\
\text { PUU/VIII/2010 tentang Status Anak Luar } \\
\text { Kawin }\end{array}$ & Moh Urip \\
\hline 11 & $\begin{array}{l}\text { Peristiwa Perkawinan Bawah Umur dan } \\
\text { Konflik Kehidupan Rumah Tangga di } \\
\text { Desa Banjar Talela Kecamatan Camplong } \\
\text { Kabupaten Sampang }\end{array}$ & Ali Mansur \\
\hline 12 & $\begin{array}{l}\text { Tradisi Ritual Rokat Pandhaba di Desa } \\
\text { Pademawu Barat Kecamatan Pademawu } \\
\text { Kabupaten Pamekasan dalam Perspektif } \\
\text { Hukum Islam }\end{array}$ & Multazam \\
\hline 13 & $\begin{array}{l}\text { Tradisi Peminangan Sellor dalam } \\
\text { Perspektif Hukum Islam (Studi Kasus di } \\
\text { Desa Ceguk Kecamatan } \\
\text { Kabupaten Pamekasan) }\end{array}$ & $\begin{array}{l}\text { A. Tulus Prasetyo } \\
\text { Aria }\end{array}$ \\
\hline 14 & $\begin{array}{l}\text { Peranan Hakim dalam Permohonan Itsbat } \\
\text { Nikah di Pengadilan Agama Pamekasan }\end{array}$ & Syaiful Anam \\
\hline 15 & $\begin{array}{l}\text { Keabsahan Anak dalam Islam } \\
\text { Konsistensi Kompilasi Hukum } \\
\text { terhadap Madzhab al-Arba'ah) }\end{array}$ & Subahri \\
\hline 16 & $\begin{array}{l}\text { Kebosanan dalam Rumah Tangga sebagai } \\
\text { Penyebab Suami Menceraikan Istrinya di } \\
\text { Desa Waru Timur Kecamatan Waru } \\
\text { Kabupaten Pamekasan }\end{array}$ & Jamilatul Qoyyimah \\
\hline 17 & $\begin{array}{l}\text { Peran Perempuan } \\
\text { Keluarga di Desa } \\
\text { Majur Barat Batu } \\
\text { Marmar Pamekasan menurut Perspektif } \\
\text { Hukum Islam }\end{array}$ & Farman Hadiyanto \\
\hline 18 & $\begin{array}{l}\text { Pembaruan Nikah di Desa Candi Burung } \\
\text { Kecamatan Proppo Kabupaten Pamekasan } \\
\text { dalam Perspektif Hukum Islam }\end{array}$ & $\begin{array}{l}\text { Raden Mohammad } \\
\text { Rizki Sahal M.A }\end{array}$ \\
\hline
\end{tabular}




\begin{tabular}{|c|c|c|}
\hline 19 & $\begin{array}{l}\text { Study Analisis Penolakan Siti Musdah } \\
\text { Mulia terhadap Pasal-pasal Poligami di } \\
\text { dalam Kompilasi Hukum Islam (KHI) }\end{array}$ & Khoirus Shodiqin \\
\hline 20 & $\begin{array}{l}\text { Upaya Istri dalam Memelihara Keutuhan } \\
\text { Rumah Tangga di Tengah Perselingkuhan } \\
\text { Suami di Desa Tanjung Kecamatan } \\
\text { Pademawu Kabupaten Pamekasan }\end{array}$ & Nurfaiqoh \\
\hline 21 & $\begin{array}{l}\text { Tradisi Penunaian Zakat Fitrah oleh } \\
\text { Tunangan di Desa Sotabar Kecamatan } \\
\text { Pasean Kabupaten Pamekasan Menurut } \\
\text { Hukum Islam }\end{array}$ & Noraini \\
\hline 22 & $\begin{array}{l}\text { Analisa Fikih Jinayah terhadap Sanksi } \\
\text { Kejahatan Kemanusiaan dalam Pasal } 9 \\
\text { UU No. } 26 \text { Tahun } 2000 \text { tentang Hak Asasi } \\
\text { Manusia }\end{array}$ & Mas'udi \\
\hline 23 & $\begin{array}{l}\text { Fenomena Kawin Sandhek Perspektif } \\
\text { Hukum Islam (Studi Kasus di Desa } \\
\text { Sokalelah Kecamatan Kadur Kabupaten } \\
\text { Pamekasan) }\end{array}$ & Suhriyanto \\
\hline 24 & $\begin{array}{l}\text { Pemahaman Masyarakat Desa Panaan } \\
\text { Kecamatan Palengaan Kabupaten } \\
\text { Pamekasan tentang Taklik Talak dalam } \\
\text { Perspektif Hukum Islam }\end{array}$ & $\begin{array}{ll}\text { Siti } & \text { Nashihatul } \\
\text { Hasanah } & \end{array}$ \\
\hline 25 & $\begin{array}{l}\text { Pertimbangan Hakim dalam Penentuan } \\
\text { Kadar Mut'ah dan Nafkah dalam Masa } \\
\text { Iddah di Pengadilan Agama Pamekasan }\end{array}$ & Raudatul Jannah \\
\hline 26 & $\begin{array}{l}\text { Tradisi Mengkhitbah Anak dalam } \\
\text { Kandungan di Desa Klampar Kecamatan } \\
\text { Proppo Kabupaten Pamekasan dalam } \\
\text { Perspektif Hukum Islam }\end{array}$ & Sitti Sulaihah \\
\hline 27 & $\begin{array}{l}\text { Kedudukan Saksi } \text { Keluarga } \\
\text { Perkara Perceraian di Pengadilan } \\
\text { Pamekasan }\end{array}$ & Robiatul Andawiyah \\
\hline
\end{tabular}




\begin{tabular}{|c|c|c|}
\hline 28 & \begin{tabular}{llr} 
Perilaku & \multicolumn{2}{c}{ Masyarakat Desa Pabian } \\
Kecamatan & Kota Sumenep Kabupaten \\
Sumenep & Dalam & Menetapkan Opsi \\
Perkawinan Sirri & &
\end{tabular} & Nurul Karimah \\
\hline 29 & $\begin{array}{l}\text { Prewedding Picture Perspektif Elite Agama } \\
\text { di Pamekasan }\end{array}$ & Try Subakti \\
\hline 30 & $\begin{array}{l}\text { Fenomena Pernikahan Sirri di Kalangan } \\
\text { Mahasiswa STAIN Pamekasan }\end{array}$ & Anisatun Nikmah \\
\hline 31 & $\begin{array}{l}\text { Studi Komparatif tentang Sistem } \\
\text { Pengelolaan Tanah Wakaf di Kalangan } \\
\text { Nahdlatul Ulama' dan Muhammadiyah di } \\
\text { Kabupaten Gresik (Telaah Hukum Islam } \\
\text { dan PP No. } 28 \text { Tahun 1977) }\end{array}$ & M. Musfir \\
\hline 32 & $\begin{array}{l}\text { Konstruksi Kebebasan Perempuan dalam } \\
\text { Menentukan Pasangan Hidup } \\
\text { (Rethingking Konsepsi Hak Ijbar dalam } \\
\text { Hukum Islam) }\end{array}$ & Holis Hendri \\
\hline 33 & $\begin{array}{l}\text { Tradisi Binsambin Pertunangan di Desa } \\
\text { Tamba Agung Timur Kecamatan } \\
\text { Ambunten Kabupaten Sumenep dalam } \\
\text { Perspektif Hukum Islam }\end{array}$ & Imam Hariri \\
\hline
\end{tabular}

Dari 33 judul di atas, yang termasuk ke dalam studi al-Ahwwâl al-Syakhshiyyah sebanyak 30 judul. Al-ahwâl al-syakhshiyah atau hukum keluarga di sini pokok kajiannya meliputi munâkahat, mawârits, washiyat, wakaf, 31 dan hibah. ${ }^{32}$ Mengenai wakaf, memang ada kemungkinan masuk ke dalam bidang ibadah apabila dilihat dari maksud orang mewakafkan hartanya (untuk kemaslahatan umum), namun dapat dikategorikan dalam bidang al-ahwâl al-syakhshiyah apabila wakaf itu wakaf zuri, yakni wakaf untuk keluarga.

\footnotetext{
31 Abû Zahrah, Al-Ahwwâl al-Syakhshiyah (Mesir: Dâr al-Fikri al-Arabi, 1957), hlm 19.

32 Djazuli menambahkan dengan hibah. Lihat A. Djazuli, "Beberapa Aspek Pengembangan Hukum Islam di Indonesia", dalam Tjun Suryaman (ed.), Hukum Islam di Indonesia:Pemikian dan Praktek (Bandung: Remaja Rosdakarya, 1991).
} 
Penelitian skripsi mahasiswa dalam kategori al-ahwwâl alsyakhshiyyah di bidang munâkahat (perkawinan) adalah sebanyak 27 judul, yaitu:

\begin{tabular}{|c|c|c|}
\hline NO & JUDUL & PENULIS \\
\hline 1 & $\begin{array}{l}\text { Kepercayaan Masyarakat terhadap Primbon } \\
\text { Pernikahan Perspektif Hukum Islam di } \\
\text { Desa Plakpak Kecamatan Pegantenan } \\
\text { Kabupaten Pamekasan }\end{array}$ & Ahmad Efendi \\
\hline 2 & $\begin{array}{l}\text { Kesadaran Suami Istri dalam Memiliki Akta } \\
\text { Kelahiran bagi Anak yng Dilahirkan pada } \\
\text { Masayarakat Desa Polagan Kecamatan } \\
\text { Galis Kabupaten Pamekasan }\end{array}$ & Sri Windartik \\
\hline 3 & $\begin{array}{l}\text { Saksi Palsu dalam Proses Perceraian di } \\
\text { Pengadilan Agama Pamekasan }\end{array}$ & Hairuddin \\
\hline 4 & $\begin{array}{l}\text { Pandangan Masyarakat tentang } \\
\text { Pelaksanaan Pencatatan Perkawinan di } \\
\text { Desa Waru Barat Kecamatan Waru } \\
\text { Kabupaten Pamekasan }\end{array}$ & Rismawati \\
\hline 5 & $\begin{array}{l}\text { Faktor Pendapatan Suami dan Istri dalam } \\
\text { Membangun Keharmonisan Rumah Tangga } \\
\text { di Kelurahan Parteker Kecamatan Kota } \\
\text { Kabupaten Pamekasan }\end{array}$ & Sulaihah \\
\hline 6 & \begin{tabular}{llr}
\multicolumn{2}{l}{ Analisis Hukum Islam atas } & Putusan \\
Mahkamah & Konstitusi & No \\
PUU/VIII/2010 & tentang Status & Anak Luar \\
Kawin & &
\end{tabular} & Moh Urip \\
\hline 7 & $\begin{array}{l}\text { Peristiwa Perkawinan Bawah Umur dan } \\
\text { Konflik Kehidupan Rumah Tangga di Desa } \\
\text { Banjar Talela Kecamatan Camplong } \\
\text { Kabupaten Sampang }\end{array}$ & Ali Mansur \\
\hline 8 & $\begin{array}{l}\text { Tradisi Ritual Rokat Pandhaba di Desa } \\
\text { Pademawu Barat Kecamatan Pademawu } \\
\text { Kabupaten Pamekasan dalam Perspektif } \\
\text { Hukum Islam }\end{array}$ & Multazam \\
\hline
\end{tabular}




\begin{tabular}{|c|c|c|}
\hline 9 & $\begin{array}{l}\text { Tradisi Peminangan Sellor dalam Perspektif } \\
\text { Hukum Islam (Studi Kasus di Desa Ceguk } \\
\text { Kecamatan Tlanakan } \\
\text { Pamekasan) }\end{array}$ & $\begin{array}{l}\text { A. Tulus Prasetyo } \\
\text { Aria }\end{array}$ \\
\hline 10 & $\begin{array}{l}\text { Peranan Hakim dalam Permohonan Itsbat } \\
\text { Nikah di Pengadilan Agama Pamekasan }\end{array}$ & Syaiful Anam \\
\hline 11 & $\begin{array}{l}\text { Keabsahan Anak dalam Islam } \\
\text { Konsistensi Kelaah } \\
\text { terhadap Madzhab al-Arba'ah) }\end{array}$ & Subahri \\
\hline 12 & $\begin{array}{l}\text { Kebosanan dalam Rumah Tangga Sebagai } \\
\text { Penyebab Suami Menceraikan Istrinya di } \\
\text { Desa Waru Timur Kecamatan Waru } \\
\text { Kabupaten Pamekasan }\end{array}$ & $\begin{array}{l}\text { Jamilatul } \\
\text { Qoyyimah }\end{array}$ \\
\hline 13 & $\begin{array}{l}\text { Peran Perempuan dalam Menafkahi } \\
\text { Keluarga di Desa Bujur Barat Batu Marmar } \\
\text { Pamekasan menurut Perspektif Hukum } \\
\text { Islam }\end{array}$ & Farman Hadiyanto \\
\hline 14 & $\begin{array}{l}\text { Pembaruan Nikah di Desa Candi Burung } \\
\text { Kecamatan Proppo Kabupaten Pamekasan } \\
\text { dalam Perspektif Hukum Islam }\end{array}$ & $\begin{array}{l}\text { Raden Mohammad } \\
\text { Rizki Sahal M.A }\end{array}$ \\
\hline 15 & $\begin{array}{l}\text { Study Analisis Penolakan Siti Musdah } \\
\text { Mulia terhadap Pasal-pasal Poligami di } \\
\text { dalam Kompilasi Hukum Islam (KHI) }\end{array}$ & Khoirus Shodiqin \\
\hline 16 & $\begin{array}{l}\text { Upaya Istri dalam Memelihara Keutuhan } \\
\text { Rumah Tangga di Tengah Perselingkuhan } \\
\text { Suami di Desa Tanjung Kecamatan } \\
\text { Pademawu Kabupaten Pamekasan }\end{array}$ & Nurfaiqoh \\
\hline 17 & $\begin{array}{l}\text { Tradisi Penunaian Zakat Fitrah oleh } \\
\text { Tunangan di Desa Sotabar Kecamatan } \\
\text { Pasean Kabupaten Pamekasan menurut } \\
\text { Hukum Islam }\end{array}$ & Noraini \\
\hline 18 & $\begin{array}{l}\text { Fenomena Kawin Sandhek } \\
\text { Perspektif } \\
\text { Hukum Islam (Studi Kasus di Desa }\end{array}$ & Suhriyanto \\
\hline
\end{tabular}




\begin{tabular}{|c|c|c|}
\hline & $\begin{array}{l}\text { Sokalelah Kecamatan Kadur Kabupaten } \\
\text { Pamekasan) }\end{array}$ & \\
\hline 19 & $\begin{array}{l}\text { Pemahaman } \begin{array}{r}\text { Masyarakat } \\
\text { Kecamatan Pesa Panaan } \\
\text { Pamekasan tentang Taklik }\end{array} \text { Talak dalam } \\
\text { Perspektif Hukum Islam }\end{array}$ & $\begin{array}{l}\text { Siti Nashihatul } \\
\text { Hasanah }\end{array}$ \\
\hline 20 & $\begin{array}{l}\text { Pertimbangan Hakim dalam Penentuan } \\
\text { Kadar Mut'ah dan Nafkah dalam Masa } \\
\text { Iddah di Pengadilan Agama Pamekasan }\end{array}$ & Raudatul Jannah \\
\hline 21 & $\begin{array}{l}\text { Tradisi Mengkhitbah Anak dalam } \\
\text { Kandungan di Desa Klampar Kecamatan } \\
\text { Proppo Kabupaten Pamekasan dalam } \\
\text { Perspektif Hukum Islam }\end{array}$ & Sitti Sulaihah \\
\hline 22 & 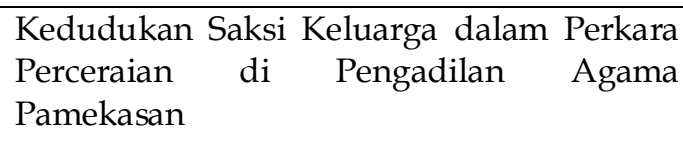 & $\begin{array}{l}\text { Robiatul } \\
\text { Andawiyah }\end{array}$ \\
\hline 23 & 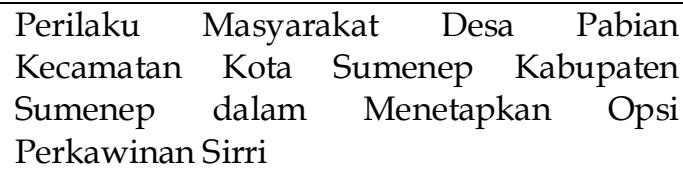 & Nurul Karimah \\
\hline 24 & $\begin{array}{l}\text { Prewedding Picture Perspektif Elite Agama di } \\
\text { Pamekasan }\end{array}$ & Try Subakti \\
\hline 25 & $\begin{array}{l}\text { Fenomena Pernikahan Sirri di Kalangan } \\
\text { Mahasiswa STAIN Pamekasan }\end{array}$ & Anisatun Nikmah \\
\hline 26 & $\begin{array}{l}\text { Konstruksi Kebebasan Perempuan dalam } \\
\text { Menentukan Pasangan Hidup (Rethingking } \\
\text { Konsepsi Hak Ijbar dalam Hukum Islam) }\end{array}$ & Holis Hendri \\
\hline 27 & $\begin{array}{l}\text { Tradisi Binsambin Pertunangan di Desa } \\
\text { Tamba Agung Timur Kecamatan Ambunten } \\
\text { Kabupaten Sumenep dalam Perspektif } \\
\text { Hukum Islam }\end{array}$ & Imam Hariri \\
\hline
\end{tabular}


Yang termasuk ke dalam bidang al-ahizâl al-syakhshiyyah di luar bidang munâkahat, seperti bidang mawârits, wakaf, dan washiyat berjumlah 2 judul, yaitu:

\begin{tabular}{|l|l|l|}
\hline NO & JUDUL & PENULIS \\
\hline 1 & $\begin{array}{l}\text { Pandangan Ibn Qoyyim Al-Jauziyah } \\
\text { terhadap al-Hiyal al-Syar'iyah dalam } \\
\text { Praktik Hibah Waris }\end{array}$ & Mahbubi \\
\hline 2 & $\begin{array}{l}\text { Studi Komparatif tentang Sistem } \\
\text { Pengelolaan Tanah Wakaf di Kalangan } \\
\text { Nahdlatul Ulama' dan Muhammadiyah di } \\
\text { Kabupaten Gresik (Telaah Hukum Islam } \\
\text { dan PP No. 28 Tahun 1977) }\end{array}$ & \\
\hline
\end{tabular}

Selain itu, terdapat 4 judul di luar bidang al-ahwâl alsyakhshiyyah, seperti kajian figh qadla', Ilmu Falak, fiqh zakat, dan figh jinâyat, yaitu:

\begin{tabular}{|l|l|l|l|}
\hline NO & JUDUL & PENULIS & BIDANG \\
\hline 1 & $\begin{array}{l}\text { Etika Profesi Advokat dalam } \\
\text { Perspektif Hukum Sslam dan } \\
\text { Hukum Positif }\end{array}$ & $\begin{array}{l}\text { Syaiful Ridho } \\
\text { Pengukuran Arah Kiblat } \\
\text { Kementerian Agama Kabupaten } \\
\text { Pamekasan }\end{array}$ & Hairul Umam Ilmu Falak \\
\hline 3 & $\begin{array}{l}\text { Analisa Fikih Jinayah terhadap } \\
\text { Sanksi Kejahatan Kemanusiaan } \\
\text { dalam Pasal 9 UU No. 26 Tahun } \\
\text { 2000 tentang Hak Asasi Manusia }\end{array}$ & Mas'udi & $\begin{array}{l}\text { Fikih } \\
\text { Jinayat }\end{array}$ \\
\hline 4 & $\begin{array}{l}\text { Implementasi Zakat Gaji di } \\
\text { Kalangan PNS Pada Kantor } \\
\text { Kementerian Agama Kabupaten } \\
\text { Pamekasan }\end{array}$ & Akhmad & Zakat \\
\hline
\end{tabular}


Data di atas memberikan tampak bahwa bidang perkawinan mendominasi tema penelitian skripsi mahasiswa AHS STAIN Pamekasan. Sebagian besar mahasiswa beralasan bahwa persoalan tentang pernikahan mudah didapatkan di sekitar mereka. Malahan, mereka memiliki pengalaman tersendiri tentang masalah perkawinan. Ahmad Efendi, misalnya,menceritakan pengalamannya berkenaan dengan pamannya yang akan menikahkan sepupu perempuannya. Beberapa bulan sebelum pelaksanaan, dirinya ikut mengantarkan pamannya kepada "orang pintar" untuk menanyakan tanggal baik pelaksanaan perkawinan. Penulis, berpandangan, beberapa mahasiswa lainnya memilih tema pernikahan karena kemudahan mendapatkan fenomana dan akses informasi berkenaan dengannya.

Terkait dengan lokus penelitian, sebanyak 19 judul penelitian mengambil lokasi di Madura, terutama Pamekasan dan Sumenep, kecuali penelitian yang dilakukan oleh M. Musfir berjudul "Studi Komparatif tentang Sistem Pengelolaan Tanah Wakaf di Kalangan Nahdlatul Ulama' dan Muhammadiyah di Kabupaten Gresik (Telaah Hukum Islam dan PP No. 28 Tahun 1977)". Mereka adalah:

\begin{tabular}{|c|c|c|c|}
\hline NO & JUDUL & PENULIS & LOKASI \\
\hline 1 & $\begin{array}{l}\text { Kepercayaan Masyarakat } \\
\text { Terhadap Primbon Pernikahan } \\
\text { Perspektif Hukum Islam di Desa } \\
\text { Plakpak Kecamatan Pegantenan } \\
\text { Kabupaten Pamekasan }\end{array}$ & Ahmad Efendi & $\begin{array}{l}\text { Pamekasan, } \\
\text { Madura }\end{array}$ \\
\hline 2 & $\begin{array}{l}\text { Kesadaran Suami Istri dalam } \\
\text { Memiliki Akta Kelahiran Bagi } \\
\text { Anak Yang Dilahirkan Pada } \\
\text { Masayarakat Desa Polagan } \\
\text { Kecamatan Galis Kabupaten } \\
\text { Pamekasan }\end{array}$ & Sri Windartik & $\begin{array}{l}\text { Pamekasan, } \\
\text { Madura }\end{array}$ \\
\hline 3 & 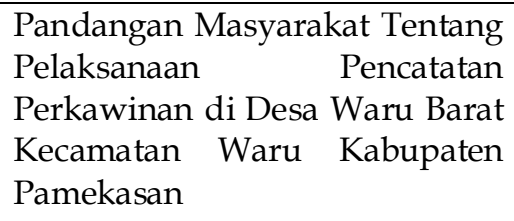 & Rismawati & $\begin{array}{l}\text { Pamekasan, } \\
\text { Madura }\end{array}$ \\
\hline
\end{tabular}




\begin{tabular}{|c|c|c|c|}
\hline 4 & 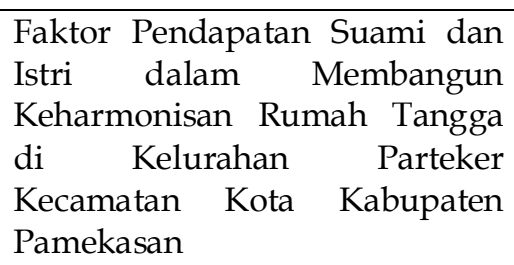 & Sulaihah & $\begin{array}{l}\text { Pamekasan, } \\
\text { Madura }\end{array}$ \\
\hline 5 & $\begin{array}{l}\text { Peristiwa Perkawinan Bawah } \\
\text { Umur dan Konflik Kehidupan } \\
\text { Rumah Tangga di Desa Banjar } \\
\text { Talela Kecamatan Camplong } \\
\text { Kabupaten Sampang }\end{array}$ & Ali Mansur & $\begin{array}{l}\text { Sampang, } \\
\text { Madura }\end{array}$ \\
\hline 6 & $\begin{array}{l}\text { Tradisi Ritual Rokat Pandhaba } \\
\text { di Desa Pademawu Barat } \\
\text { Kecamatan } \\
\text { Kabupaten Pamekasan dalam } \\
\text { Perspektif Hukum Islam }\end{array}$ & Multazam & $\begin{array}{l}\text { Pamekasan, } \\
\text { Madura }\end{array}$ \\
\hline 7 & $\begin{array}{l}\text { Tradisi Peminangan Sellor } \\
\text { dalam Perspektif Hukum Islam } \\
\text { (Studi Kasus di Desa Ceguk } \\
\text { Kecamatan Tlanakan Kabupaten } \\
\text { Pamekasan) }\end{array}$ & $\begin{array}{ll}\text { A. } & \text { Tulus } \\
\text { Prasetyo Aria }\end{array}$ & $\begin{array}{l}\text { Pamekasan, } \\
\text { Madura }\end{array}$ \\
\hline 8 & $\begin{array}{l}\text { Kebosanan dalam Rumah } \\
\text { Tangga Sebagai Penyebab } \\
\text { Suami Menceraikan Istrinya di } \\
\text { Desa Waru Timur Kecamatan } \\
\text { Waru Kabupaten Pamekasan }\end{array}$ & $\begin{array}{l}\text { Jamilatul } \\
\text { Qoyyimah }\end{array}$ & $\begin{array}{l}\text { Pamekasan, } \\
\text { Madura }\end{array}$ \\
\hline 9 & $\begin{array}{l}\text { Peran Perempuan Dalam } \\
\text { Menafkahi Keluarga di Desa } \\
\text { Bujur Barat Batu Marmar } \\
\text { Pamekasan Menurut Perspektif } \\
\text { Hukum Islam }\end{array}$ & $\begin{array}{l}\text { Farman } \\
\text { Hadiyanto }\end{array}$ & $\begin{array}{l}\text { Pamekasan, } \\
\text { Madura }\end{array}$ \\
\hline 10 & $\begin{array}{l}\text { Pembaruan Nikah di Desa } \\
\text { Candi Burung Kecamatan } \\
\text { Proppo Kabupaten Pamekasan } \\
\text { dalam Perspektif Hukum Islam }\end{array}$ & $\begin{array}{l}\text { Raden } \\
\text { Mohammad } \\
\text { Rizki Sahal } \\
\text { M.A }\end{array}$ & $\begin{array}{l}\text { Pamekasan, } \\
\text { Madura }\end{array}$ \\
\hline
\end{tabular}




\begin{tabular}{|c|c|c|c|}
\hline & & & \\
\hline 11 & \begin{tabular}{ll}
\multicolumn{2}{c}{ Upaya Istri dalam Memelihara } \\
Keutuhan Rumah Tangga di \\
Tengah Perselingkuhan Suami \\
di Desa Tanjung & Kecamatan \\
Pademawu & Kabupaten \\
Pamekasan &
\end{tabular} & Nurfaiqoh & $\begin{array}{l}\text { Pamekasan, } \\
\text { Madura }\end{array}$ \\
\hline 12 & $\begin{array}{l}\text { Tradisi Penunaian Zakat Fitrah } \\
\text { oleh Tunangan di Desa Sotabar } \\
\text { Kecamatan Pasean Kabupaten } \\
\text { Pamekasan Menurut Hukum } \\
\text { Islam }\end{array}$ & Noraini & $\begin{array}{l}\text { Pamekasan, } \\
\text { Madura }\end{array}$ \\
\hline 13 & $\begin{array}{lrr}\text { Fenomena } & \text { Kawin } & \text { Sandhek } \\
\text { Perspektif Hukum Islam (Studi } \\
\text { Kasus di Desa } & \text { Sokalelah } \\
\text { Kecamatan Kadur } & \text { Kabupaten } \\
\text { Pamekasan) } & & \end{array}$ & Suhriyanto & $\begin{array}{l}\text { Pamekasan, } \\
\text { Madura }\end{array}$ \\
\hline 14 & $\begin{array}{l}\text { Pemahaman Masyarakat Desa } \\
\text { Panaan Kecamatan Palengaan } \\
\text { Kabupaten Pamekasan Tentang } \\
\text { Taklik Talak dalam Perspektif } \\
\text { Hukum Islam }\end{array}$ & $\begin{array}{l}\text { Siti Nashihatul } \\
\text { Hasanah }\end{array}$ & $\begin{array}{l}\text { Pamekasan, } \\
\text { Madura }\end{array}$ \\
\hline 15 & $\begin{array}{l}\text { Tradisi Mengkhitbah Anak } \\
\text { dalam Kandungan di Desa } \\
\text { Klampar Kecamatan Proppo } \\
\text { Kabupaten Pamekasan dalam } \\
\text { Perspektif Hukum Islam }\end{array}$ & Sitti Sulaihah & $\begin{array}{l}\text { Pamekasan, } \\
\text { Madura }\end{array}$ \\
\hline 16 & $\begin{array}{llr}\text { Perilaku } & \text { Masyarakat } & \text { Desa } \\
\text { Pabian } & \text { Kecamatan } & \text { Kota } \\
\text { Sumenep } & \text { Kabupaten Sumenep } \\
\text { dalam } & \text { Menetapkan } & \text { Opsi } \\
\text { Perkawinan Sirri } & \end{array}$ & $\begin{array}{l}\text { Nurul } \\
\text { Karimah }\end{array}$ & $\begin{array}{l}\text { Sumenep, } \\
\text { Madura }\end{array}$ \\
\hline 17 & $\begin{array}{l}\text { Prewedding Picture Perspektif } \\
\text { Elite Agama di Pamekasan }\end{array}$ & Try Subakti & $\begin{array}{l}\text { Pamekasan, } \\
\text { Madura }\end{array}$ \\
\hline 18 & Fenomena Pernikahan Sirri di & Anisatun & Pamekasan, \\
\hline
\end{tabular}




\begin{tabular}{|l|l|l|l|}
\hline & $\begin{array}{l}\text { Kalangan Mahasiswa STAIN } \\
\text { Pamekasan }\end{array}$ & Nikmah & Madura \\
\hline 19 & $\begin{array}{l}\text { Tradisi Binsambin Pertunangan } \\
\text { di Desa Tamba Agung Timur } \\
\text { Kecamatan Amam Hariri } \\
\text { Kabupaten Sumenep dalam } \\
\text { Perspektif Hukum Islam }\end{array}$ & $\begin{array}{l}\text { Sumenep, } \\
\text { Madura }\end{array}$ & \\
\hline
\end{tabular}

Secara sosiologis, penelitian di atas disebut sebagai penelitian lokalitas. Konsep lokalitas ini dikontraskan dengan konsep globalitas atau globalisasi. ${ }^{33}$ Istilah lokalitas dibatasi oleh sekat geografis secara ketat. ${ }^{34}$ Karenanya lokalitas bisa berbentuk suku bangsa atau bisa juga komunitas.

Istilah suku bangsa, menurut Brian M.du Toit, menunjuk pada individu-individu guna mempertimbangkan di manakah seseorang atau dirinya termasuk atau dimasukkan sebagai anggotanya; yaitu yang didasarkan atas latar belakang kebudayaan. ${ }^{35}$ Sedangkan Schemerhorn memaknai suku bangsa sebagai sebuah kolektivitas di dalam sebuah masyarakat yang besar dan memiliki leluhur yang sama baik secara nyata maupun dugaan; memiliki memori sejarah masa lalu yang sama, dan memiliki sebuah fokus budaya pada satu atau lebih elemen simbolik yang ditetapkan sebagai lambang kesukuan. ${ }^{36}$ Unsur-unsur simbolik tersebut meliputi, antara lain, pola kekerabatan, pola keberagamaan, hubungan fisik (karena berada dalam suatu tempat), bentuk-bentuk bahasa atau dialek, ${ }^{37}$ afiliasi

\footnotetext{
${ }^{33}$ Riza Noer Arfani, “Globalisasi, Karakteristik dan Implikasi”, Ekonomi Politik Digital Journal Al-Manär, Edisi I (2004), hlm. 1

34 Wang Gungwu, Lokal and National: a Dialogue between Tradition and Modernity, Makalah disampaikan pada International Conference on "Ethnic Chinese in Singapore and Malaysia: a Dialogue between Tradition and Modernity", Singapura, 30 Juini 2001: http:// www.une.edu.au/malaysiasoc/Wang.pdf.

${ }_{35}$ Brian M. du Toit (ed.), Ethnicity in Modern Africa (Colorado: Westview, 1978), hlm. 3. 36 R.A. Schemerhorn, Comparative Ethnic Relation: A Framework of Theory and Research (New York: Random House, 1970), hlm. 12.

37 Berkaitan dengan elemen kesamaan bahasa ini mendapatkan perhatian khusus B. Setiawan yang menyatakan bahwa seringkali kesatuan bahasa menjadi penguat dalam satu kesatuan sosial, sehingga ia dapat disebut sebagai satu suku bangsa. Lihat
} 
kabilah (clan), kebangsaan, atau berbagai kombinasi dari ini semua. Dengan kata lain, suku bangsa merupakan sebuah konsep budaya yang berintikan penganutan norma, nilai, keyakinan, simbol, dan praktik budaya bersama. ${ }^{38}$

Sedangkan komunitas yang berasal dari kata 'communis'39 yang berarti 'umum atau berbagi bersama',40 dimaknai sebagai sekelompok sosial organisme yang berada dalam sebuah lingkungan yang biasanya memiliki kepentingan dan nilai bersama. Dalam komunitas manusia, tujuan, keyakinan, preferensi, kebutuhan, dan sejumlah keadaan lainnya menjadi pengikat kohesivitas di antara mereka.

Sebuah komunitas memproteksi dirinya melalui sebuah jarak fisik untuk meyakinkan dan menjaga dunia luar betul-betul berada di luar. Kesan tentang komunitas ini tampak seperti sebuah ide tentang kehidupan desa tradisional. Penduduk desa umumnya memiliki sifat jujur, berterus terang, konservatif, dan ramah; tidak banyak melakukan perjalanan jauh dan jarang dikunjungi orang orang asing; kehidupan mereka berpusat pada keluarga dan tetangga; privasi individu di antara mereka biasanya terbatas; pendapat di antara anggota keluarga dan tetangga menjadi sangat penting; dan moral para penduduk desa tampak superior dibandingkan dengan kaum urban. ${ }^{41}$

Pemilihan Madura sebagai tempat penelitian skripsi mahasiswa dapat dihubungkan dengan tempat tinggal mahasiswa yang hampir semuanya bertempat tinggal di Madura. Ini dapat dilihat dari data berikut:

\begin{tabular}{|l|l|l|l|}
\hline NO & \multicolumn{1}{|c|}{ JUDUL } & PENULIS & ALAMAT \\
\hline 1 & $\begin{array}{l}\text { Kepercayaan Masyarakat } \\
\text { Terhadap Primbon Pernikahan }\end{array}$ & $\begin{array}{l}\text { Ahmad } \\
\text { Efendi }\end{array}$ & $\begin{array}{l}\text { Dusun Secang } \\
\text { Desa Plakpak }\end{array}$ \\
\hline
\end{tabular}

B. Setiawan, et al., Ensiklopedi Nasional Indonesia, Jilid 14 (Jakarta: PT. Delta Pamungkas, 1997), hlm. 326

38 Chris Barker, Cultural Studies; Teori dan Praktik, terj. Tim Kunci Cultural Studies Center (Yogyakarta: Bentang, 2005), hlm. 257.

39 Communis di sini merupakan kombinasi dari prefiks 'con' yang berarti 'bersama' dan 'munis' yang berarti mengerjakan sesuatu untuk melayani seseorang.

40 Peter Davies (ed.), The American Heritage Dictionary on the English Language (New York: Dell Publishing Co., Inc., 1977), hlm. 147.

41 Baca Richard Critchfield, Villages (New York: Doubleday, 1981). 


\begin{tabular}{|c|c|c|c|}
\hline & $\begin{array}{l}\text { Perspektif Hukum Islam di } \\
\text { Desa Plakpak Kecamatan } \\
\text { Pegantenan Kabupaten } \\
\text { Pamekasan }\end{array}$ & & $\begin{array}{l}\text { Kecamatan } \\
\text { Pegantenan Kab. } \\
\text { Pamekasan }\end{array}$ \\
\hline 2 & $\begin{array}{l}\text { Kesadaran Suami Istri dalam } \\
\text { Memiliki Akta Kelahiran Bagi } \\
\text { Anak Yang Dilahirkan Pada } \\
\text { Masayarakat Desa Polagan } \\
\text { Kecamatan Galis Kabupaten } \\
\text { Pamekasan }\end{array}$ & $\begin{array}{l}\text { Sri } \\
\text { Windartik }\end{array}$ & $\begin{array}{l}\text { Desa Candi } \\
\text { Polagan Kec. } \\
\text { Galis }\end{array}$ \\
\hline 3 & $\begin{array}{l}\text { Saksi Palsu dalam Proses } \\
\text { Perceraian di Pengadilan } \\
\text { Agama Pamekasan }\end{array}$ & Hairuddin & $\begin{array}{l}\text { Ds. Pademawu } \\
\text { Kec. Pademawu }\end{array}$ \\
\hline 4 & $\begin{array}{l}\text { Etika Profesi Advokat dalam } \\
\text { Perspektif Hukum Islam dan } \\
\text { Hukum Positif }\end{array}$ & $\begin{array}{l}\text { Syaiful } \\
\text { Ridho }\end{array}$ & \\
\hline 5 & $\begin{array}{l}\text { Pandangan Masyarakat } \\
\text { Tentang Pelaksanaan } \\
\text { Pencatatan Perkawinan di } \\
\text { Desa Waru Barat Kecamatan } \\
\text { Waru Kabupaten Pamekasan }\end{array}$ & Rismawati & $\begin{array}{l}\text { Waru Barat } \\
\text { Pamekasan }\end{array}$ \\
\hline 6 & $\begin{array}{l}\text { Faktor Pendapatan Suami dan } \\
\text { Istri dalam Membangun } \\
\text { Keharmonisan Rumah Tangga } \\
\text { di Kelurahan Parteker } \\
\text { Kecamatan Kota Kabupaten } \\
\text { Pamekasan }\end{array}$ & Sulaihah & $\begin{array}{l}\text { Jalan Parteker } \\
\text { Gang I/30 }\end{array}$ \\
\hline 7 & $\begin{array}{l}\text { Penerapan Kebijakan } \\
\text { Pengukuran Arah Kiblat } \\
\text { Kementerian Agama } \\
\text { Kabupaten Pamekasan }\end{array}$ & $\begin{array}{l}\text { Hairul } \\
\text { Umam }\end{array}$ & $\begin{array}{l}\text { Desa Klompang } \\
\text { Barat Kec. Pakong }\end{array}$ \\
\hline 8 & $\begin{array}{l}\text { Implementasi Zakat Gaji di } \\
\text { Kalangan PNS Pada Kantor } \\
\text { Kementerian Agama } \\
\text { Kabupaten Pamekasan }\end{array}$ & $\begin{array}{l}\text { Akhmad } \\
\text { Maimun }\end{array}$ & $\begin{array}{l}\text { Dusun Selatan } \\
\text { Desa Toronan } \\
\text { Pamekasan }\end{array}$ \\
\hline
\end{tabular}




\begin{tabular}{|c|c|c|c|}
\hline 9 & $\begin{array}{l}\text { Peristiwa Perkawinan Bawah } \\
\text { Umur dan Konflik Kehidupan } \\
\text { Rumah Tangga di Desa Banjar } \\
\text { Talela Kecamatan Camplong } \\
\text { Kabupaten Sampang }\end{array}$ & Ali Mansur & $\begin{array}{l}\text { Desa Tambaan } \\
\text { Kec. Camplong }\end{array}$ \\
\hline 10 & $\begin{array}{l}\text { Tradisi Ritual Rokat Pandhaba } \\
\text { di Desa Pademawu Barat } \\
\text { Kecamatan Pademawu } \\
\text { Kabupaten Pamekasan dalam } \\
\text { Perspektif Hukum Islam }\end{array}$ & Multazam & $\begin{array}{l}\text { Ds. Pandiyangan } \\
\text { Kec. } \\
\text { Robatal/Desa } \\
\text { Pademawu Barat } \\
\text { Pamekasan }\end{array}$ \\
\hline 11 & $\begin{array}{l}\text { Tradisi Peminangan Sellor } \\
\text { dalam Perspektif Hukum } \\
\text { Islam (Studi Kasus di Desa } \\
\text { Ceguk Kecamatan Tlanakan } \\
\text { Kabupaten Pamekasan) }\end{array}$ & $\begin{array}{l}\text { A. Tulus } \\
\text { Prasetyo } \\
\text { Aria }\end{array}$ & $\begin{array}{l}\text { Desa Sopa'ah } \\
\text { Pademawu } \\
\text { Pamekasan }\end{array}$ \\
\hline 12 & $\begin{array}{l}\text { Peranan Hakim Dalam } \\
\text { Permohonan Itsbat Nikah di } \\
\text { Pengadilan Agama Pamekasan }\end{array}$ & $\begin{array}{l}\text { Syaiful } \\
\text { Anam }\end{array}$ & $\begin{array}{l}\text { Ds. Ceguk Kec. } \\
\text { Tlanakan }\end{array}$ \\
\hline 13 & $\begin{array}{l}\text { Kebosanan dalam Rumah } \\
\text { Tangga Sebagai Penyebab } \\
\text { Suami Menceraikan Istrinya di } \\
\text { Desa Waru Timur Kecamatan } \\
\text { Waru Kabupaten Pamekasan }\end{array}$ & $\begin{array}{l}\text { Jamilatul } \\
\text { Qoyyimah }\end{array}$ & $\begin{array}{l}\text { Ds. Waru Timur } \\
\text { Kec. Waru }\end{array}$ \\
\hline 14 & $\begin{array}{l}\text { Peran Perempuan Dalam } \\
\text { Menafkahi Keluarga di Desa } \\
\text { Bujur Barat Batu Marmar } \\
\text { Pamekasan Menurut } \\
\text { Perspektif Hukum Islam }\end{array}$ & $\begin{array}{l}\text { Farman } \\
\text { Hadiyanto }\end{array}$ & $\begin{array}{l}\text { Desa Bujur Barat } \\
\text { Kec, Batumarmar }\end{array}$ \\
\hline 15 & $\begin{array}{l}\text { Pembaruan Nikah di Desa } \\
\text { Candi Burung Kecamatan } \\
\text { Proppo Kabupaten Pamekasan } \\
\text { dalam Perspektif Hukum } \\
\text { Islam }\end{array}$ & $\begin{array}{l}\text { Raden } \\
\text { Mohammad } \\
\text { Rizki Sahal } \\
\text { M.A }\end{array}$ & $\begin{array}{l}\text { Perumahan } \\
\text { Nyalabuh Indah } \\
\text { Blok H V/a } \\
\text { Nyalabuh }\end{array}$ \\
\hline 16 & Upaya Istri dalam Memelihara & Nurfaiqoh & Dusun Jumiang \\
\hline
\end{tabular}




\begin{tabular}{|c|c|c|c|}
\hline & $\begin{array}{l}\text { Keutuhan Rumah Tangga di } \\
\text { Tengah Perselingkuhan Suami } \\
\text { di Desa Tanjung Kecamatan } \\
\text { Pademawu Kabupaten } \\
\text { Pamekasan }\end{array}$ & & $\begin{array}{l}\text { Desa Tanjung } \\
\text { Kec. Pademawu }\end{array}$ \\
\hline 17 & $\begin{array}{l}\text { Tradisi Penunaian Zakat Fitrah } \\
\text { oleh Tunangan di Desa } \\
\text { Sotabar Kecamatan Pasean } \\
\text { Kabupaten Pamekasan } \\
\text { Menurut Hukum Islam }\end{array}$ & Noraini & $\begin{array}{l}\text { Ds. Sotabar Kec. } \\
\text { Pasean }\end{array}$ \\
\hline 18 & $\begin{array}{l}\text { Fenomena Kawin Sandhek } \\
\text { Perspektif Hukum Islam } \\
\text { (Studi Kasus di Desa Sokalelah } \\
\text { Kecamatan Kadur Kabupaten } \\
\text { Pamekasan) }\end{array}$ & Suhriyanto & $\begin{array}{l}\text { Desa Sokalelah } \\
\text { Kec. Kadur }\end{array}$ \\
\hline 19 & $\begin{array}{l}\text { Pemahaman Masyarakat Desa } \\
\text { Panaan Kecamatan Palengaan } \\
\text { Kabupaten Pamekasan } \\
\text { Tentang Taklik Talak dalam } \\
\text { Perspektif Hukum Islam }\end{array}$ & $\begin{array}{l}\text { Siti } \\
\text { Nashihatul } \\
\text { Hasanah }\end{array}$ & $\begin{array}{l}\text { Panaan Kec. } \\
\text { Palengaan }\end{array}$ \\
\hline 20 & $\begin{array}{l}\text { Pertimbangan Hakim dalam } \\
\text { Penentuan Kadar Mut'ah dan } \\
\text { Nafkah dalam Masa Iddah di } \\
\text { Pengadilan Agama Pamekasan }\end{array}$ & $\begin{array}{l}\text { Raudatul } \\
\text { Jannah }\end{array}$ & $\begin{array}{l}\text { Ds. Pakamban } \\
\text { Kec. Paragaan }\end{array}$ \\
\hline 21 & $\begin{array}{l}\text { Tradisi Mengkhitbah Anak } \\
\text { dalam Kandungan di Desa } \\
\text { Klampar Kecamatan Proppo } \\
\text { Kabupaten Pamekasan dalam } \\
\text { Perspektif Hukum Islam }\end{array}$ & Sitti Sulaihah & $\begin{array}{l}\text { Ponjanan Timur } \\
\text { Kec. Batu } \\
\text { Marmar/Desa } \\
\text { Klampar Kec. } \\
\text { Proppo } \\
\text { Pamekasan }\end{array}$ \\
\hline 22 & $\begin{array}{l}\text { Kedudukan Saksi Keluarga } \\
\text { Dalam Perkara Perceraian di } \\
\text { Pengadilan Agama Pamekasan }\end{array}$ & $\begin{array}{l}\text { Robiatul } \\
\text { Andawiyah }\end{array}$ & $\begin{array}{l}\text { Desa Pandan Kec. } \\
\text { Galis }\end{array}$ \\
\hline 23 & $\begin{array}{l}\text { Perilaku Masyarakat Desa } \\
\text { Pabian Kecamatan Kota }\end{array}$ & $\begin{array}{l}\text { Nurul } \\
\text { Karimah }\end{array}$ & $\begin{array}{l}\text { Jl. Slamet Riadi } \\
\text { No. } 27 \text { A. }\end{array}$ \\
\hline
\end{tabular}




\begin{tabular}{|l|l|l|l|}
\hline & $\begin{array}{l}\text { Sumenep Kabupaten Sumenep } \\
\text { Dalam Menetapkan Opsi } \\
\text { Perkawinan Sirri }\end{array}$ & $\begin{array}{l}\text { Desa Pabian Kec. } \\
\text { Kota Sumenep }\end{array}$ \\
\hline 24 & $\begin{array}{l}\text { Prewedding Picture Perspektif } \\
\text { Elite Agama di Pamekasan }\end{array}$ & Try Subakti & $\begin{array}{l}\text { Desa Pademawu } \\
\text { Barat Pamekasan }\end{array}$ \\
\hline 25 & $\begin{array}{l}\text { Fenomena Pernikahan Sirri di } \\
\text { Kalangan Mahasiswa STAIN } \\
\text { Pamekasan }\end{array}$ & $\begin{array}{l}\text { Anisatun } \\
\text { Nikmah }\end{array}$ & $\begin{array}{l}\text { Jl. Blimbing 300 } \\
\text { Karang Duak } \\
\text { Sumenep }\end{array}$ \\
\hline 26 & $\begin{array}{l}\text { Tradisi Binsambin Pertunangan } \\
\text { di Desa Tamba Agung Timur } \\
\text { Kecamatan Ambunten } \\
\text { Kabupaten Sumenep dalam } \\
\text { Perspektif Hukum Islam }\end{array}$ & Imam Hariri & $\begin{array}{l}\text { Desa Ambunten } \\
\text { Kec. Ambunten }\end{array}$ \\
\hline
\end{tabular}

Mereka memilih tema penelitian yang berkembang di desa di mana mereka tinggal atau di komunitas (seperti STAIN dan Pengadilan Agama) selama beberapa waktu mereka hidup atau berada di tempat tersebut. Anisatun Nikmah, misalnya, menceritakan pengalamannya selama 3,5 tahun kuliah di STAIN Pamekasan. Selama itu pula, ia melihat dan mendengarkan curahan hati beberapa kawannya yang melakukan perkawinan sirri. Pengalamannya tersebut kemudian ia angkaat sebagai tema penelitian skripsinya. Begitu pula dengan Suhriyanto yang mengangkat tema Kawin Sandhek, di mana tema tersebut berkenaan dengan pengalaman kawan desanya yang mengalami peristiwa tersebut. Beberapa mahasiswa juga mendapatkan inspirasi tema penelitian setelah sebulan mereka praktik lapangan di Pengadilan Agama Pamekasan.

Dalam tradisi hermeneutika, keterkaitan antara penulis dan teks yang ditulis dapat dibahas dengan menggunakan model hermeneutika Schleiermacher. Dalam hubungan ini, Schleiermacher, menyatakan bahwa ketika teks dilempar ke ruang publik, ia tidak bisa hidup dengan nafasnya sendiri. Dengan kata lain, makna teks adalah makna yang dikehendaki oleh pengarangnya. Karenanya, penafsiran merupakan sebuah kegiatan reproduktif, yakni memberikan makna dengan tidak terlepas dari pengarangnya. 42 Bahkan menurutnya,

42 Kees Bertens, Filsafat Barat dalam Abad XX (Jakarta: Gramedia, 1981), hlm. 231. 
seorang penafsir harus masuk ke dalam waktu dan alam pikiran pengarangnya. Seorang penafsir mesti membayangkan dan mengkonfirmasi bagaimana pemikiran dan maksud pengarang.

\section{Trend Epistemologis Kajian Hukum Islam di STAIN Pamekasan}

Terdapat tiga tradisi epistemologis dalam kajian hukum Islam, yaitu epistemologi normatif-deduktif, epistemologi historis-induktif, dan epistemologi integralistik. Ketiga epistemologi tersebut terdapat dalam penelitian skripsi mahasiswa AHS STAIN Pamekasan. Terdapat 6 mahasiswa yang melakukan penelitian dalam wilayah epistemologi normatif-deduktif, 12 judul skripsi digolongkan ke dalam epistemologi historis-induktif, dan 15 judul skripsi dimasukkan ke dalam kategori epistemologi integralistik. Datanya adalah sebagai berikut:

Kajian Normatif-Deduktif

\begin{tabular}{|l|l|l|}
\hline NO & JUDUL & PENULIS \\
\hline 1 & $\begin{array}{l}\text { Etika Profesi Advokat dalam Perspektif } \\
\text { Hukum Islam dan Hukum Positif }\end{array}$ & Syaiful Ridho \\
\hline 2 & $\begin{array}{l}\text { Analisis Hukum Islam Atas Putusan } \\
\text { Mahkamah Konstitusi No 46 PUU /VIII/2010 } \\
\text { Tentang Status Anak Luar Kawin }\end{array}$ & Moh Urip \\
\hline 3 & $\begin{array}{l}\text { Keabsahan Anak dalam Islam (Telaah } \\
\text { Konsistensi Kompilasi Hukum Islam Terhadap } \\
\text { Madzhab Al-Arba'ah) }\end{array}$ & Subahri \\
\hline 4 & $\begin{array}{l}\text { Study Analisis Penolakan Siti Musdah Mulia } \\
\text { Terhadap Pasal-pasal Poligami di dalam } \\
\text { Kompilasi Hukum Islam (KHI) }\end{array}$ & Khoirus Shodiqin \\
\hline 5 & $\begin{array}{l}\text { Analisa Fikih Jinayah Terhadap Sanksi } \\
\text { Kejahatan Kemanusiaan dalam Pasal 9 UU No. } \\
\text { 26 Tahun 2000 Tentang Hak Asasi Manusia }\end{array}$ & Mas'udi \\
\hline 6 & $\begin{array}{l}\text { Konstruksi Kebebasan Perempuan dalam } \\
\text { Menentukan Pasangan Hidup (Rethingking } \\
\text { Konsepsi Hak Ijbar dalam Hukum Islam) }\end{array}$ & Holis Hendri \\
\hline
\end{tabular}


Kajian Historis-Induktif

\begin{tabular}{|c|c|c|}
\hline NO & JUDUL & PENULIS \\
\hline 1 & $\begin{array}{l}\text { Kesadaran Suami Istri dalam Memiliki Akta } \\
\text { Kelahiran Bagi Anak Yang Dilahirkan Pada } \\
\text { Masayarakat Desa Polagan Kecamatan Galis } \\
\text { Kabupaten Pamekasan }\end{array}$ & Sri Windartik \\
\hline 2 & $\begin{array}{lccc}\text { Saksi Palsu dalam Proses } & \text { Perceraian di } \\
\text { Pengadilan Agama Pamekasan } & & \end{array}$ & Hairuddin \\
\hline 3 & $\begin{array}{l}\text { Pandangan Masyarakat Tentang Pelaksanaan } \\
\text { Pencatatan Perkawinan di Desa Waru Barat } \\
\text { Kecamatan Waru Kabupaten Pamekasan }\end{array}$ & Rismawati \\
\hline 4 & $\begin{array}{l}\text { Faktor Pendapatan Suami dan Istri dalam } \\
\text { Membangun Keharmonisan Rumah Tangga di } \\
\text { Kelurahan Parteker Kecamatan Kota Kabupaten } \\
\text { Pamekasan }\end{array}$ & Sulaihah \\
\hline 5 & $\begin{array}{l}\text { Penerapan Kebijakan Pengukuran Arah Kiblat } \\
\text { Kementerian Agama Kabupaten Pamekasan }\end{array}$ & Hairul Umam \\
\hline 6 & $\begin{array}{l}\text { Peranan Hakim Dalam Permohonan Itsbat } \\
\text { Nikah di Pengadilan Agama Pamekasan }\end{array}$ & Syaiful Anam \\
\hline 7 & $\begin{array}{l}\text { Kebosanan dalam Rumah Tangga Sebagai } \\
\text { Penyebab Suami Menceraikan Istrinya di Desa } \\
\text { Waru Timur Kecamatan Waru Kabupaten } \\
\text { Pamekasan }\end{array}$ & $\begin{array}{l}\text { Jamilatul } \\
\text { Qoyyimah }\end{array}$ \\
\hline 8 & $\begin{array}{l}\text { Upaya Istri dalam Memelihara Keutuhan } \\
\text { Rumah Tangga di Tengah Perselingkuhan } \\
\text { Suami di Desa Tanjung Kecamatan Pademawu } \\
\text { Kabupaten Pamekasan }\end{array}$ & Nurfaiqoh \\
\hline 9 & $\begin{array}{l}\text { Pertimbangan Hakim dalam Penentuan Kadar } \\
\text { Mut'ah dan Nafkah dalam Masa Iddah di } \\
\text { Pengadilan Agama Pamekasan }\end{array}$ & Raudatul Jannah \\
\hline 10 & Kedudukan Saksi Keluarga Dalam Perkara & Robiatul \\
\hline
\end{tabular}




\begin{tabular}{|l|l|l|}
\hline & Perceraian di Pengadilan Agama Pamekasan & Andawiyah \\
\hline 11 & $\begin{array}{l}\text { Perilaku Masyarakat Desa Pabian Kecamatan } \\
\text { Kota Sumenep Kabupaten Sumenep Dalam } \\
\text { Menetapkan Opsi Perkawinan Sirri }\end{array}$ & Nurul Karimah \\
\hline 12 & $\begin{array}{l}\text { Fenomena Pernikahan Sirri di Kalangan } \\
\text { Mahasiswa STAIN Pamekasan }\end{array}$ & $\begin{array}{l}\text { Anisatun } \\
\text { Nikmah }\end{array}$ \\
\hline
\end{tabular}

\section{Kajian Integrated}

\begin{tabular}{|c|c|c|}
\hline NO & JUDUL & PENULIS \\
\hline 1 & $\begin{array}{l}\text { Kepercayaan Masyarakat } \text { Terhadap } \\
\text { Primbon Pernikahan Perspektif } \\
\text { Hukum Islam di Desa Plakpak } \\
\text { Kecamatan Pegantenan Kabupaten } \\
\text { Pamekasan }\end{array}$ & Ahmad Efendi \\
\hline 2 & $\begin{array}{l}\text { Implementasi Zakat Gaji di Kalangan } \\
\text { PNS Pada Kantor Kementerian } \\
\text { Agama Kabupaten Pamekasan }\end{array}$ & Akhmad Maimun \\
\hline 3 & $\begin{array}{l}\text { Peristiwa Perkawinan Bawah Umur } \\
\text { dan Konflik Kehidupan Rumah } \\
\text { Tangga di Desa Banjar Talela } \\
\text { Kecamatan Camplong Kabupaten } \\
\text { Sampang }\end{array}$ & Ali Mansur \\
\hline 4 & $\begin{array}{l}\text { Tradisi Ritual Rokat Pandhaba di } \\
\text { Desa Pademawu Barat Kecamatan } \\
\text { Pademawu Kabupaten Pamekasan } \\
\text { dalam Perspektif Hukum Islam }\end{array}$ & Multazam \\
\hline 5 & $\begin{array}{l}\text { Tradisi Peminangan Sellor dalam } \\
\text { Perspektif Hukum Islam (Studi Kasus } \\
\text { di Desa Ceguk Kecamatan Tlanakan } \\
\text { Kabupaten Pamekasan) }\end{array}$ & A. Tulus Prasetyo Aria \\
\hline 6 & $\begin{array}{l}\text { Peran Perempuan Dalam Menafkahi } \\
\text { Keluarga di Desa Bujur Barat Batu } \\
\text { Marmar Pamekasan } \quad \text { Menurut }\end{array}$ & Farman Hadiyanto \\
\hline
\end{tabular}




\begin{tabular}{|c|c|c|}
\hline & Perspektif Hukum Islam & \\
\hline 7 & $\begin{array}{llr}\text { Pembaruan } & \text { Nikah di Desa } & \text { Candi } \\
\text { Burung } & \text { Kecamatan } & \text { Proppo } \\
\text { Kabupaten } & \text { Pamekasan } & \text { dalam } \\
\text { Perspektif Hukum Islam } & \end{array}$ & $\begin{array}{l}\text { Raden Mohammad } \\
\text { Rizki Sahal M.A }\end{array}$ \\
\hline 8 & $\begin{array}{l}\text { Tradisi Penunaian Zakat Fitrah oleh } \\
\text { Tunangan di Desa Sotabar Kecamatan } \\
\text { Pasean Kabupaten Pamekasan } \\
\text { Menurut Hukum Islam }\end{array}$ & Noraini \\
\hline 9 & $\begin{array}{l}\text { Fenomena Kawin Sandhek Perspektif } \\
\text { Hukum Islam (Studi Kasus di Desa } \\
\text { Sokalelah Kecamatan Kadur } \\
\text { Kabupaten Pamekasan) }\end{array}$ & Suhriyanto \\
\hline 10 & $\begin{array}{l}\text { Pemahaman Masyarakat Desa Panaan } \\
\text { Kecamatan Palengaan Kabupaten } \\
\text { Pamekasan Tentang Taklik Talak } \\
\text { dalam Perspektif Hukum Islam }\end{array}$ & Siti Nashihatul Hasanah \\
\hline 11 & $\begin{array}{l}\text { Tradisi Mengkhitbah Anak dalam } \\
\text { Kandungan di Desa Klampar } \\
\text { Kecamatan Proppo Kabupaten } \\
\text { Pamekasan dalam Perspektif Hukum } \\
\text { Islam }\end{array}$ & Sitti Sulaihah \\
\hline 12 & $\begin{array}{l}\text { Prewedding Picture Perspektif Elite } \\
\text { Agama di Pamekasan }\end{array}$ & Try Subakti \\
\hline 13 & $\begin{array}{l}\text { Tradisi Binsambin Pertunangan di } \\
\text { Desa Tamba Agung Timur Kecamatan } \\
\text { Ambunten Kabupaten Sumenep } \\
\text { dalam Perspektif Hukum Islam }\end{array}$ & Imam Hariri \\
\hline 14 & $\begin{array}{lrrr}\text { Fenomena } & \text { Pernikahan } & \text { Sirri } & \text { di } \\
\text { Kalangan } & \text { Mahasiswa } & \text { STAIN } \\
\text { Pamekasan } & & \end{array}$ & Anisatun Nikmah \\
\hline 15 & $\begin{array}{l}\text { Studi Komparatif Tentang Sistem } \\
\text { Pengelolaan Tanah Wakaf di }\end{array}$ & M. Musfir \\
\hline
\end{tabular}




\begin{tabular}{|l|l|l|}
\hline $\begin{array}{l}\text { Kalangan Nahdlatul Ulama' dan } \\
\text { Muhammadiyah di Kabupaten Gresik } \\
\text { (Telaah Hukum Islam dan PP No. 28 } \\
\text { Tahun 1977) }\end{array}$ & \\
\hline
\end{tabular}

Berkenaan dengan epistemologi normatif-deduktif, Fazlur Rahman mengistilahkannya sebagai kajian normative Islam, ${ }^{43}$ Amin Abdullah memberikan istilah sebagai kajian keislaman normativitas, ${ }^{44}$ dan Akh. Minhaji mengistilahkan sebagai normative Islam. 45

Dalam tradisi hukum Islam 'Abid al-Jabiri menyebutnya sebagai epistemologi bayâni, yakni suatu episteme yang menjadikan nash (al-Qur'an dan al-Hadits), ijmâ', dan qiyâs sebagai sumber dasar dalam pengetahuan, terutama dalam menggambarkan ajaran-ajaran Islam. Dalam konteks ini, nalar bayâni bertumpu pada pemeliharaan teks (nash), dan oleh karenanya, aktivitas intelektualnya berada dalam hegemoni al-ashl, dan nalarnya terkungkung dalam tiga pola pemikiran yaitu, al-istinbâth, al-qiyâs, dan al-istidlâl.

Tradisi epistemologi yang kedua adalah epistemologi historisinduktif. Fazlur Rahman memberikan istilah atas tradisi epistemologi tersebut sebagai historical Islam, ${ }^{46}$ Amin Abdullah memberikan istilah sebagai kajian keislaman historisitas, ${ }^{47}$ dan Akh. Minhaji mengistilahkan sebagai kajian empirical Islam,48 dan al-Jabiri menyebutnya sebagai epistemologi burhâni.

43 Fazlur Rahman. "Islamic Modernism: Its Scope, Method and Alternative." International Journal of Middle East, vol. 1 (1970), hlm. 317-32.

${ }_{44}$ Amin Abdullah, "Paradigma Alternatif Pengembangan Usul Fiqh", dalam Mazhab Jogja: Menggagas Paradigma Ushul Figh Kontemporer (Yogyakarta: AR-RUZZ Press, 2002)

45 Akh. Minhaji, "Pendekatan Sejarah dalam Kajian Hukum Islam," Mukaddimah No. 8 Th V/1999, 63-88. Lihat juga Idem, "A Problem of Methodological Approach to Islamic Law Studies", al-Jami'ah Journal of Islamic Studies, No. 63/VI (1999)

46 Fazlur Rahman. "Islamic Modernism: Its Scope, Method and Alternative." International Journal of Middle East 1 (1970), 317-32.

47 Amin Abdullah, "Paradigma Alternatif Pengembangan Usul Fiqh", dalam Mazhab Jogja: Menggagas Paradigma Ushul Figh Kontemporer (Yogyakarta: AR-RUZZ Press, 2002)

48 Akh. Minhaji, "Pendekatan Sejarah dalam Kajian Hukum Islam," Mukaddimah No. 8 Th V/1999, 63-88. Lihat juga Idem, "A Problem of Methodological Approach to Islamic Law Studies", al-Jami'ah Journal of Islamic Studies, No. 63/VI (1999) 
Sistem epistemik burhâni bertumpu sepenuhnya pada seperangkat kemampuan intelektual manusia, baik berupa indera, pengalaman, maupun rasio bagi upaya pemerolehan pengetahuan tentang semesta dengan mendasarkannya pada keterkaitan antara sebab dan akibat (kausalitas), bahkan juga bagi solidasi perspektif realitas yang sistematis, valid, dan postulatif. ${ }^{9}$

Sistem pemikiran burhâni sangath berbeda jika dibandingkan dengan sistem pemikiran bayâni yang secara a priori telah menjadikan realitas kewahyuan (al-Quran dan sunah) yang terkemas dalam wacana bahasa dan agama sebagai acuan berpijak bagi pemerolehan pengetahuan. Sedangkan nalar burhâni dimaksudkan untuk menganalisis faktor kausalitas dari tema-tema yang dikajinya dan merumuskan suatu kebenaran, yaitu pengetahuan yang bersifat benar dan meyakinkan, atau yang dikenal dalam bahasa Aristoteles sebagai "ilmu". .50

Epistemologi ketiga adalah epistemologi integratifinterkonektif 51 atau integralistik. ${ }^{52}$ Model integralistik ini dapat dilakukan dengan terlebih dahulu membuat inferensi tekstual dan historis (sosial-empiris-kultural), untuk kemudian dibuatkan analisisnya yang bersifat terpadu (inferensi integralistik).

Secara metodologis, model inferensi integralistik di atas sesungguhnya hanya menyajikan suatu model penelitian ilmiah (sosial) alternatif yang dekat dengan aspirasi Islam. Namun demikian, rancangan metodologi alternatif tersebut bisa dijadikan inspirasi bagi pengembangan studi hukum Islam yang mengapresiasi dan memasukkan data-data sosial empiris dalam analisisnya.

Kajian hukum Islam di STAIN Pamekasan menunjukkan trend kajian dalam epistemologi integrated. Kondisi ini bertolak belakang dengan beberapa penelitian sebelumnya yang menujukkan bahwa

49Ibid., hlm. 384. Lihat juga, Muhammad Abid al-Jabiri, Isykâliyat al-Fikr al-Arabi al$M u$ 'âshir, (Beirut: Markaz Dirasat al-Wihdah al-Arabiyah, 1994), hlm. 59.

${ }^{50}$ Lihat SembodoArdi Widodo, "Nalar Bayani, 'Irfani, dan Burhani dan Implikasinya terhadap Keilmuan Pesantren", Hermeneia, Jurnal Kajian Islam Interdisipliner, Vol. 6, Nomor 1, (Januari-Juni 2007), hlm. 65-92.

51 Amin Abdullah, Islamic Studies di Perguruan Tinggi: Pendekatan Integratif-Interkonektif (Yogyakarta: Pustaka Pelajar, 2006),

${ }_{52}$ Mahsun Fuad, Hukum Islam Indonesia: Dari Nalar Partisipatoris Hingga Emansipatoris (Yogyakarta: LkiS, 2005), hlm. 263. 
Mohammad Hefni

kajian hukum Islam atau keislaman di PTAI pada umumnya masih bersifat deduksi. Hal ini ditunjukkan oleh penelitian-penelitian, misalnya, Akh. Minhaji dan Kamaruzzaman Bustamam-Ahmad yang berjudul "Arah Baru Studi Hukum Islam di Indonesia", 53 Syamsul Anwar berjudul "Pengembangan Metode Penelitian Hukum Islam",54 dan Musahadi HAM 55 yang berjudul "Pemikiran Ulang Perguruan Tinggi Agama". Kesemuanya menyimpulkan bahwa studi keislaman, termasuk hukum Islam, di Indonesia, termasuk di PTAI pada umumnya mengidap problem epistemologis yang serius, yakni studi keislaman lebih kental dengan pendekatan rasionalisme spekulatif yang berwatak deduktif. Sementara pendekatan empirisme praktis yang berwatak induktif kurang mendapat tempat yang layak. Selama ini pengembangan keilmuan keislaman di PTAI relatif stagnan karena kuatnya pendekatan normative-teologis, sehingga yang terjadi adalah justifikasi terhadap kebenaran ajaran, doktrin dan teori-teori normatif agama.

\section{Penutup}

Dari pembahasan pada bagian sebelumnya, dapat disimpulkan bahwa: Pertama, secara ontologis, dari 33 judul skripsi mahasiswa yang lulus tahun 2013, yang termasuk ke dalam studi alahwôl al-syakhshiyyah sebanyak 30 judul. Pokok kajian al-ahwâl alsyakhshiyyah meliputi munâkahat, mawârits, washiyat, wakaf, dan hibah. Penelitian skripsi mahasiswa dalam kategori al-ahwâl al-syakhshiyyah di bidang perkawinan adalah sebanyak 27 judul, sedangkan yang termasuk ke dalam bidang al-ahwâl al-syakhshiyyah di luar bidang munakahat, seperti bidang mawârits, wakaf, dan washiyat adalah sebanyak 2 judul. Selain itu, terdapat 4 judul di luar bidang al-ahwâl al-syakhshiyyah, seperti kajian figh qadla', Ilmu Falak, Fiqh zakat, dan fiqh jinayat, sebanyak 4 judul. Dari data tersebut menunjukkan bahwa bidang perkawinan mendominasi tema penelitian skripsi mahasiswa

53 Akh. Minhaji dan Kamaruzzaman Bustamam-Ahmad, "Arah Baru Studi Hukum Islam di Indonesia", Jurnal Perta, Vol. VI/03 (2005)

54 Syamsul Anwar, "Pengembangan Metode Penelitian Hukum Islam" dalam Mazhab Jogja: Menggagas Paradigma Ushul Figh Kontemporer (Yogyakarta: AR-RUZZ Press, 2002), hlm.147-148.

55 Musahadi HAM, "Pemikiran Ulang Perguruan Tinggi Agama", Suara Merdeka, tanggal 11 Juli 2009. 
AHS STAIN Pamekasan. Terkait dengan lokus penelitian, sebanyak 19 judul penelitian mengambil lokasi di Madura, terutama Pamekasan dan Sumenep. Secara sosiologis, penelitian di atas disebut sebagai penelitian lokalitas. Dalam tradisi hermeneutika, keterkaitan antara penulis dan teks yang ditulis dapat dibahas dengan menggunakan model hermeneutika Friedrich Schleiermacher dan Wilhelm Dilthey.

Kedua, terdapat tiga tradisi epistemologis dalam kajian hukum Islam, yaitu epistemologi normatif-deduktif, epistemologi historisinduktif, dan epistemologi integralistik. Ketiga epistemologi tersebut terdapat dalam penelitian skripsi mahasiswa AHS STAIN Pamekasan. Terdapat 6 mahasiswa yang melakukan penelitian dalam wilayah epistemologi normatif-deduktif, 12 judul skripsi digolongkan ke dalam epistemologi historis-induktif, dan 15 judul skripsi dimasukkan ke dalam kategori epistemologi integralistik. Kajian hukum Islam di STAIN Pamekasan menunjukkan trend kajian dalam epistemologi integrated. Kondisi ini bertolak belakang dengan beberapa penelitian sebelumnya yang menujukkan bahwa kajian hukum Islam atau keislaman di PTAI pada umumnya masih bersifat deduksi.

\section{Daftar Pustaka:}

Abdullah, Amin. "Paradigma Alternatif Pengembangan Usul Fiqh", dalam Mazhab Jogja: Menggagas Paradigma Ushul Figh Kontemporer. Yogyakarta: AR-RUZZ Press, 2002.

Abdullah, Amin. Islamic Sudies di Perguruan Tinggi: Pendekatan Integratif-Interkonektif. Yogyakarta: Pustaka Pelajar, 2006.

Amin A. and N. Thrift. Cities, Reimagining the Urban. Cambridge: Polity Press, 2002.

Anderson, Bennedict. Imagined Community: Komunitas-komunitas Terbayang. Yogyakarta: Insist dan Pustaka Pelajar, 2002.

Anwar, Syamsul. " Pengembangan Metode Penelitian Hukum Islam " dalam Mazhab Jogja: Menggagas Paradigma Ushul Figh Kontemporer. Yogyakarta: AR-RUZZ Press, 2002.

Anwar, Syamsul. "Teori Hukum Hukum Islam al-Ghazali dan Pengembangan Metode Penemuan Hukum Islam", dalam M. Amin Abdullah et al., Tafsir Baru Studi Islam dalam Era Multi Kultural. Yogyakarta: Kurnia Kalam Semesta, 2002. 
Mohammad Hefni

Arfani, Riza Noer. "Globalisasi, Karakteristik dan Implikasi”, Ekonomi Politik Digital Journal Al-Manär, Edisi I (2004).

Azizy, A.Qadri. Eklektisisme Hukum Nasional, Kompetisi antara Hukum Islam dan Hukum Nasional. Yogyakarta; Gama Media, 2002.

Barker, Chris. Cultural Studies; Teori dan Praktik, terj. Tim Kunci Cultural Studies Center. Yogyakarta: Bentang, 2005.

Bertens, Kees. Filsafat Barat dalam Abad XX. Jakarta: Gramedia, 1981.

Bleicher, Josef. Hermeneutika Kontemporer, terj. Ahmad Norma Permata. Yogyakarta:Fajar Pustaka, 2003.

Brah, A. Cartographies of Diaspora. London Routledge, 1996.

Bungin Burhan, Analisis Data Penelitian Kualitatif: Pemahaman Filosofis dan Metodologis ke Arah Penguasaan Model Aplikatif. Jakarta: Raja Grafindo Persada, 2008.

Butsurî, Nûr al-Dîn. Maqâshid al-Syarî'ah: al-Tasyrî' al-Islâmî alMu'âshir bayn Thumuh al-Mujtahid wa Qushûr al-Ijtihâd. Beirut: Dâr al-Thali'ah, 2000.

Coomans, Mikhail. Manusia Dayak: Dahulu, Sekarang, Masa Depan. Jakarta: PT. Gramedia, 1987.

Critchfield, Richard. Villages. New Yc ibleday, 1981.

Djazuli, A. "Beberapa Aspek Pengembangan Hukum Islam di Indonesia", dalam Tjun Suryaman (ed.), Hukum Islam di Indonesia:Pemikian dan Praktek. Bandung: Remaja Rosdakarya, 1991.

Djazuli, A. Ilmu Figh Penggalian, Perkembangan, dan Penerapannya. Jakarta: Prenada Media, 2005.

du Toit, Brian M. (ed.), Ethnicity in Modern Africa. Colorado: Westview, 1978.

Esposito, John L. (ed.), The Oxford Encyclopaedia of the Modern Muslim World, Vol. I. New York: Oxford University Press, 1995.

Faiz, Fakhrudin. Hermenutika Qur'ani: Antara Teks, Konteks, dan Kontekstualisasi. Yogyakarta: Penerbit Qalam, 2003.

Fazlur Rahman. "Islamic Modernism: Its Scope, Method and Alternative." International Journal of Middle East 1 (1970)

Fuad, Mahsun. Hukum Islam Indonesia: Dari Nalar Partisipatoris Hingga Emansipatoris. Yogyakarta: LkiS, 2005.

Ghazâlî, al-. Mi'yar al-Ilm. Mesir: Dar al-Ma'arif, 1960. 
Giddens, Anthony. Kapitalisme dan Teori Sosial Modern: Suatu Analisis Karya-tulis Marx, Durkheim, dan Max Weber, terj. Soeheba Kramadibrata. Jakarta: UI-Press, 1986.

Gungwu, Wang. Lokal and National: a dialogue between tradition and modernity, Makalah disampaikan pada International Conference on "Ethnic Chinese in Singapore and Malaysia: a dialogue between Tradition and modernity", Singapura, 30 Juini 2001: http://www.une.edu.au/malaysiasoc/Wang.pdf.

Hallaq, Wael B. Sejarah Teori Hukum Islâm: Pengantar Ushul Figh Madzhab Sunni, terj. E. Kusnadiningrat \& Abdul Haris bin Wahid. Jakarta: PT Raja Grafindo Persada, 2000.

Hanafi, Hasan. Min al-'Aqidah ila al-Tsaurah, Jilid 1. Kairo: Maktabah al-Matbuli.

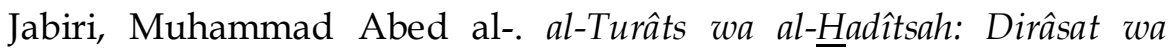
Munâqasyat. Beirut: al-Markaz al-Tsaqafi al-'Arabi, 1991.

Jabiri, Muhammad Abed al-. Bunyah al-Aql al-Arabi: Dirâsah Tahliliyah Naqdiyah li Nudhumi al-Ma'rifah fí al-Tsaqafah al-Arabiyah. Beirut : Markaz Dirasat al-Wihdah al-Arabiyah, 1990.

Jabiri, Muhammad Abed al-. Isykâliyat al-Fikr al-Arabi al-Mu'âshir. Beirut: Markaz Dirasat al-Wihdah al-Arabiyah, 1994.

Kahmad, Dadang. Sosiologi Agama. Jakarta: Remaja Rosdakarya, 2000.

Kahn, Joel S. Constituting the Minangkabau: Peasant, Culture, and Modernity in Colonial Indonesia. Oxford: BERG, 1993.

Kartanegara, Mulyadi. "Fondasi Metafisik Bangunan Epistemologi Islam", dalam M. Amin Abdullah et al. Menyatukan Kembali Ilmu-ilmu Agama dan Umum:Upaya Mempertemukan Epistemologi Islam dan Umum. Yogyakarta: Sunan Kalijaga Press, 2003.

Khallâf, Abd al-Wahhab. 'Ilm Ushûl al-Fiqh. Kuwait: Dâr al-Qalam, tt.

Koentjaroningrat (ed.). Masalah-masalah Pembangunan: Bunga Rampai Antropologi Terapan. Jakarta: LP3ES, 1982.

Luke, Timothy W. "New World Order or Neo-world Order: Power, Politics and Ideology in Informationalizing Globalization", dalam M. Feather-stone, et.al (eds.). Global Modernities. London: Sage Publications, 1995.

Martin, James G. and Franklin, Clyde W. Minority Group Relations. Ohio: Charles E. Merrill Publishing Company, 1973. 
Mohammad Hefni

Millum, Trevor. Tramps and Their Axcuses: A Study of the Writing of Travellers in Borneo in the $19^{\text {th }}$ and $20^{\text {th }}$ Centuries. Center for Southest Asean Studies at the University of Hull, 1994.

Minhaji, Akh. "A Problem of Methodological Approach to Islamic Law Studies", al-Jami'ah Journal of Islamic Studies, No. 63/VI (1999)

Minhaji, Akh. "Pendekatan Sejarah dalam Kajian Hukum Islam," Mukaddimah No. 8 Th V/1999, 63-88.

Morewedge, Parviz. Essays in Islamic Philosophy, Theology, and Mysticism. New York: The Departement of Philosophy The State University of New York, 1995.

Mudzhar, M. Atho'. "Pendekatan Sosiologi dalam Studi Hukum Islam", dalam M. Amin Abdullah, et al., Mencari Islam: Studi Islam dengan Berbagai Pendekatan. Yogyakarta: Tiara Wacana, 2000.

Muhajir, Noeng Metode Penelitian Kualitatif. Yogyakarta: Rake Sarasin, 1996.

Musahadi HAM, "Pemikiran Ulang Perguruan Tinggi Agama", Suara Merdeka, tanggal 11 Juli 2009.

Nur Kholis, “Konsep Epistemologi Hukum Islam: Perspezktif Muhammad Abed Al-Jabiri", Fenomena, Vol. 2 No. 1 (Maret 2004).

Palmer, Richard E. Hermeneutika, Teori Baru Mengenai Interpretasi, terj. Musnur Hery. Yogyakarta: Pustaka Pelajar, 2003.

Peter Davies (ed.). The American Heritage Dictionary on the English Language. New York: Dell Publishing Co., Inc., 1977.

Picard, Michel. "Cultural Tourism, Nation-Building, and Regional Culture: The Making of the Balinese Identity", dalam Michel Picard and Robert E. Wood (eds), Tourism, Ethnicity, and the State in Asian and Pacific Societies. Honolulu: University of Hawai Press, 1997.

Praja, Juhaya S. Filsafat Hukum Islam. Bandung; LPPM UIB, 1995.

Rahman, Fazlur. "Islamic Modernism: Its Scope, Method and Alternative." International Journal of Middle East 1 (1970), hlm. 317-32.

Ricoeur, Paul. Filsafat Wacana, Membelah Makna dalam Anatomi Bahasa, terj. Musnur Hery. Yogyakarta: Ircisod, 2003. 
Safi, Louay. Ancangan Metodologi Alternatif: Sebuah Refleksi Perbandingan Metode Penelitian Sosial dan Barat. Yogyakarta: Tiara Wacana, 2001.

Said, Edward W. Orientalism. London and Henley: Routledge and Paul Kegan, 1978.

Schemerhorn, R.A. Comparative Ethnic Relation: A Framework of Theory and Research. New York: Random House, 1970.

Setiawan, B. et.al., Ensiklopedi Nasional Indonesia, Jilid 14. Jakarta: PT. Delta Pamungkas, 1997.

Sirry, Mun'im A. "Memperkenalkan Fiqh Abu Ishaq al-Syathibi", Jurnal Ulumul Qur'an, Vol. V No. 1 (1999)

Sumaryono, E. Hermeneutik, Sebuah Metode Filsafat. Yogyakarta: Kanisius,1999.

Thomson, John B. Hermeneutics and the Human Sciences, Essays on Language, Action and Interpretation. Cambridge: Cambridge University, 1982.

Tönnies, Fedinand. Community and Society, trans. C.P. Loomis. East Lansing: Michigan State University Press, 1957.

'Ubaydi, Hammadi al-. al-Syâthibî wa Maqâshid al-Syarî'ah. Tripoli: Lajnah al-Huffadz 'alâ al-Turâts al-Islâmî, 1992.

Weber, Mark. Economy and Society: An Outline of Interpretative Sociology. Berkeley: University of California Press, 1978.

Widodo, Sembodo Ardi. "Nalar Bayani, 'Irfani, dan Burhani dan Implikasinya terhadap Keilmuan Pesantren", Hermeneia, Jurnal Kajian Islam Interdisipliner, Vol. 6, Nomor 1, (Januari-Juni 2007).

Z. Bauman. Community: Seeking Safety in an Insecure World. Cambridge: Polity Press, 2001.

Zahrah, Abû. Al-Ahwâl al-Syakhshiyah. Mesir: Dâr al-Fikr al-Arabi, 1957.

Zaid, Nashr Hamid Abu. Hermeneutika Inklusif. Yogyakarta: PT LKIS Pelangi Aksara, 2004. 